\title{
Giovanni Antonio Bazzi, Allegories of Love: Emblematic Ardor
}

\author{
Liana De Girolami Cheney \\ SIEALE, University of Coruna, Spaị
}

\begin{abstract}
Giovanni Antonio Bazzi (1477-1549), also known as Il Sodoma, was a Milanese painter who developed his mature style in Siena during the early Cinquecento. Between 1505 and 1510, under the tutelage of the Chigi and Petrucci families, Bazzi depicted mythological paintings focusing on the personifications of love both terrestrial and celestial. This paper looks at two such works. In one, there hangs on a sycamore tree a classical cartello with the Latin inscription Celestes, meaning celestial or heavenly, providing the title for the painting Amore Celeste (Celestial Love, Figure 3). A woman, as the personification of love, stands in front of two altars. She ignites one urn with fire and at the same time pours water over another burning fire. In the second work, a tondo with the theme of Terrestrial Love and Celestial Love, Bazzi considered the mischievousness of Venus' children Eros and Anteros (Figure 12). These paintings are mythological and poetical delights with complex symbolism, here analyzed in terms of their iconography in relation to classical influences and Renaissance Neoplatonic love or furor divinus. ${ }^{1}$ The paradoxical quest of Renaissance Neoplatonic love was to fuse pagan love with Christian love. For the humanists of the time (Bembo, Colonna, Poliziano, Ficino and Pico) this moral dilemma was a philosophical puzzle, but for artists (Botticelli, Nicoletto da Modena, Pinturicchio and Bazzi) the theme was a pictorial challenge.
\end{abstract}

Keywords: Allegories, love, iconography, poetry, Neoplatonism, Sienese patronage, Sodoma

\section{Introduction}

Giovanni Antonio Bazzi, a Piedmontese painter, was born in Vercelli (near Milan) in 1477 and died in Siena in 1549. He was trained in the Milanese school and consequently was influenced by Leonardo da Vinci's style in studying nature (landscape), with its emphasis on the soft modeling of figures and careful disegno (rendering). Bazzi travelled from Milan to Siena, Florence and Rome between 1500 and 1549 to find patronage. In his sojourns in Florence and Rome, Bazzi was under the artistic spell of the classical tradition in art as well as the painters Sandro Botticelli (1445-1510), Nicoletto da Modena (1490-1569), Bernardino Pinturicchio (1454-1513), and Raphael Sanzio (1483-1520).

This brief study deals with three points: Bazzi's self-portraits; his nicknames; and an iconographical analysis of two allegorical paintings on love: Amore Celeste and Terrestrial Love and Celestial Love, considering the cultural and religious background as well as providing an iconological interpretation.

Bazzi's self-portraits reveal his energetic and eccentric personality, as seen in the traditionally-accepted self-depiction in the fresco cycle of Saint Benedict of 1505 in the Abbey of Monte Oliveto in Monte Oliveto Maggiore in Siena, and also in Giorgio Vasari's woodcut from the Vite of 1568 (Figure 1). For other Bazzi self-portraits, I would like to suggest the Ecce Homo of 1510 at the Brera Pinacoteca in Milan and the 
Allegorical Figure of 1535-45 in the Collection of Giovanni Molli at the Accademia Carrara in Bergamo (compare Figures 1 and 2). Stylistically, when comparing the suggested self-portraits with those authenticated self-portraits, the facial physiognomy is identical.

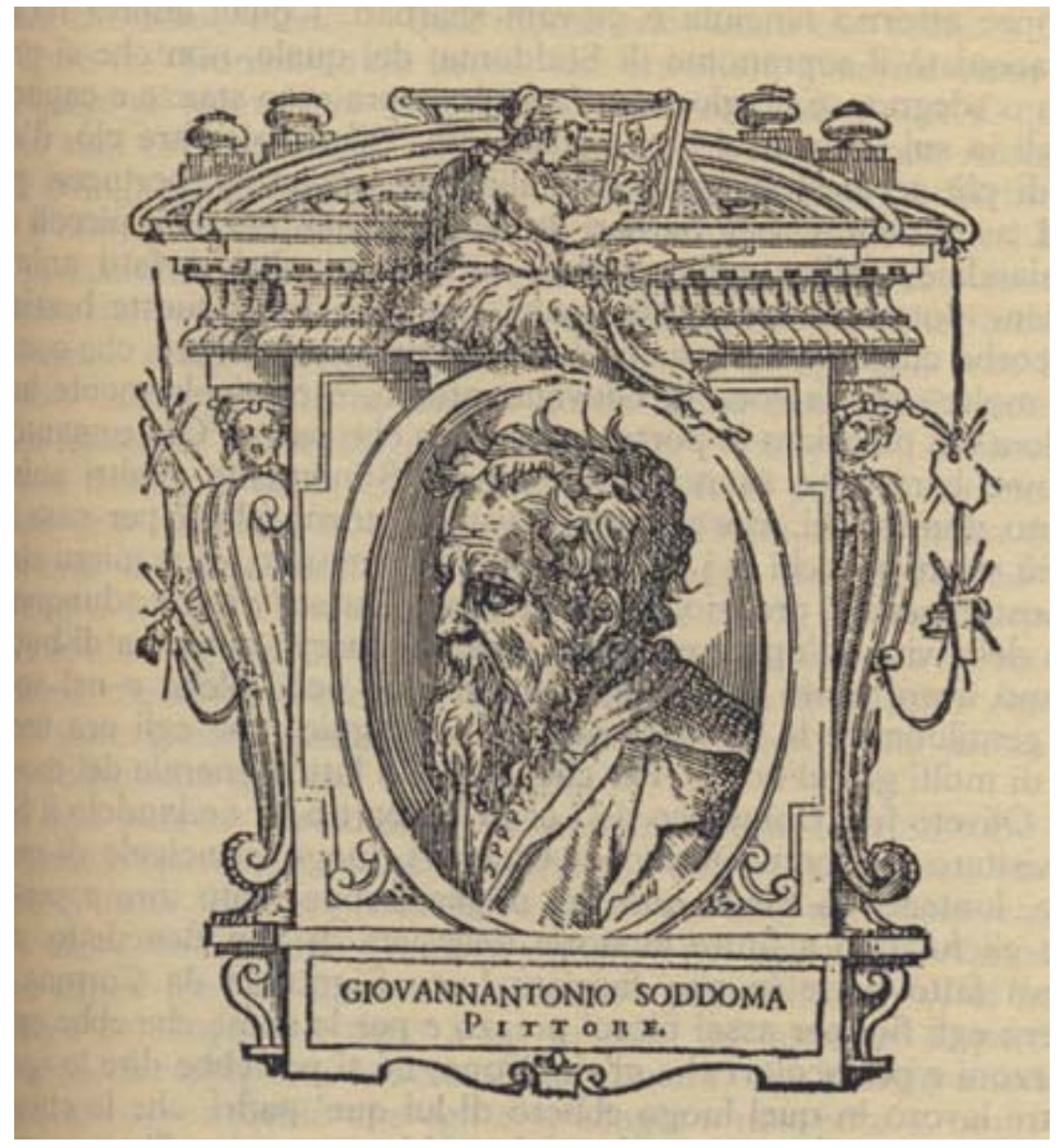

Figure 1. Giorgio Vasari, Giovanni Antonio Bazzi, woodcut portrait of 1568 in the Vite. 


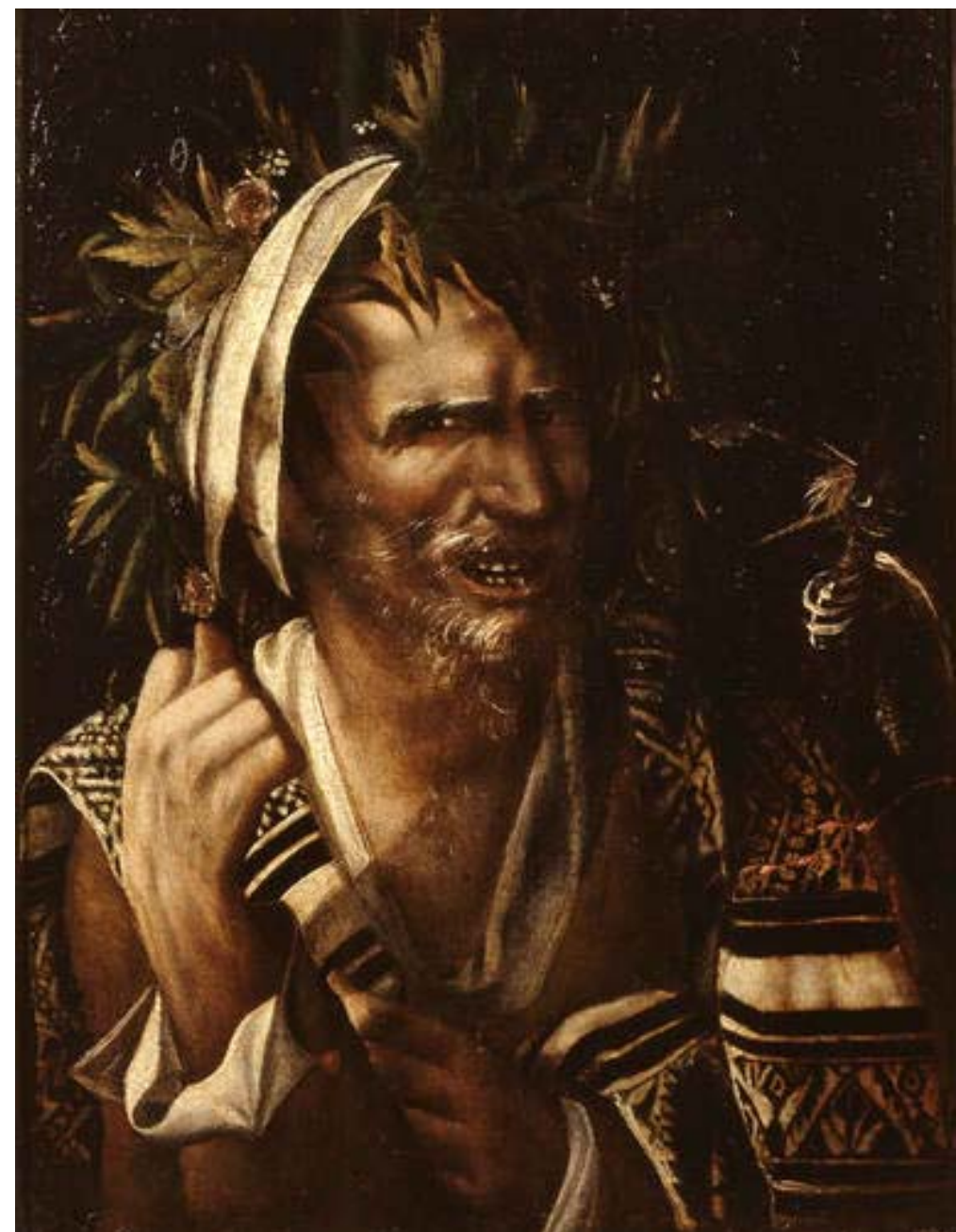

Figure 2. Giovanni Antonio Bazzi, Allegorical Figure (Self-Portrait?), 1530-1539. Collection of Giovanni Morelli (1891). Accademia Carrara, Bergamo.

Bazzi's earliest biographer was Giorgio Vasari, who in his Vite of 1568 praised his drawings and colorito (coloration) but criticized his bizzareria (extravagance), which consisted in the collection of exotic animals or bestie; his inability to handle capricious habits; his unkempt appearance; his unruly life; and his tendency to spout bad jokes, as seen in the vulgar hand gesture and bizarre attire in the Bergamo Self-Portrait as an Allegorical Figure. Vasari also noted that Bazzi was a composer of lewd songs with indecorous overtones, which he proudly sang. ${ }^{2}$

Research on this painter and his works has been sporadic and highly dependent on the work of Robert H.H. Cust, who in 1906 produced a significant and careful study of archival documents; to date it is still the most complete monograph on Bazzi. More recent research includes that of Enzo Carli, who organized the largest Bazzi exhibition (to date) in Siena in 1950; Andrée Hayum's doctoral dissertation on Bazzi in 1976 at New

\footnotetext{
2 See Giorgio Vasari, Le vite de' piú eccellenti pittori, scultori et architettori nelle redazioni del 1550 e 1568, eds. Rosanna Bettarini and Paola Barocchi (Florence: S.P.E.S., 1976; hereafter BB Vasari), V, pp. 381-390, esp. pp. 381 and 382, on the vita (life) of Bazzi. Although he disapproved of Bazzi's behavior, Vasari collected his drawings in his Libro dei Disegni. See Licia Collobi Ragghianti, Il Libro de’ Disegni del Vasari, 2 vols (Florence: Archittetura, 1973); and BB Vasari, V:387.

${ }^{2}$ See BB Vasari, V:381-390.
} 
York University; Roberto Bartalini's entries on Bazzi for the exhibition on Domenico Beccafumi e il Suo Tempo in Siena in 1988; and in 2007, Daniele Tedeschi's revised and updated version of Cust's book, which includes a list of Bazzi's paintings.

Through the centuries, Bazzi has been nicknamed Il Sodoma. It is an appellation that has intrigued art historians, although I do not plan to delve into this academic dilemma - or plan to resolve it - but I briefly want to make some observations. The family name of Giovanni Antonio might have been Razzi and not Bazzi. ${ }^{3}$ Errors in calligraphic or orthographic interpretations when writing or copying documents are plausible reasons for this discrepancy. A second nickname attached to him is Mattaccio, from matto, an Italian colloquial word for a person acting in a peculiar manner, a weird behavior, and the colloquial Italian suffix accio, referring to a person who acts as a bully (e.g., Tomasaccio for Masaccio, the nickname for the Florentine painter). ${ }^{4}$ This funny nickname, Mattaccio, at the same time derogatory and endearing, was given to Bazzi by the monks of the Monte Oliveto Maggiore Order when he was painting the cycle of Saint Benedict of Siena for their abbey in Chiusuri in 1505.

The nickname Sodoma or Soddoma is the artist's own appellation. When in Siena in 1515, Bazzi ran and won the Palio di Siena, a famous, competitive horse race. At the completion of the race, the public and functionaries were curious about the intrusion of this new competitor and asked him what was his name and he yelled: So doma, So doma, which means "I tame this horse". ${ }^{5}$ In Italian, the verb domare means to tame or to master. Hence, the community started to call him Il Sodoma, a name Bazzi never challenged. Vasari, who disliked Bazzi, manipulated this nickname Sodoma to allude to the collection and quantity of beasts that Bazzi kept in his home. ${ }^{6}$ Art historians have focused on the sexual aspect of the word and not the cultural background of the artist.

In 1510, Bazzi married Beatrice de Luca d'Egidio (Galli). They had two children, Apelles, who died during childbirth in 1511 and whose godfather was the painter Girolamo Genga (1476-1551), and Faustina, born in 1512; she married Bartolomeo Neroni, known as Il Riccio (d. 1573), a painter trained by Bazzi. In his paintings, Bazzi employed as models his beautiful wife and children. ${ }^{7}$

There is substantial information on Bazzi's involvement with religious patrons, namely the prominent Sienese Benedictine order of Monte Oliveto, for example the frescoes in the main cloister of the Abbey of Monte Oliveto Maggiore, dating to 1505, and the San Bernardino cycle of 1518 in the Oratory of San Bernardino. Another patron was the Dominican Order, e.g., the stories of Saint Catherine of 1525 in the Chapel of Saint Catherine in the Basilica of San Domenico. ${ }^{8}$ But there is limited information about Bazzi's allegorical

\footnotetext{
${ }^{3}$ See Robert Henry Hobart Cust, Giovanni Antonio Bazzi, Sodoma: The Man and the Painter (London: John Murray, 1906); Henri Hauvette, Le Sodoma: biographie critique (Paris: Renouard, 1911; repr. Laurenz, 1912); Enzo Carli, Mostra delle opera di Giovanni Antonio Bazzi detto Il Sodoma (Siena: Pinacoteca, 1950); Enzo Carli, Le Storie di San Benedetto a Monteoliveto Maggiore (Milan: Silvana, 1950; reissued 1980); André Hyman, Giovanni Antonio Bazzi, Il Sodoma (New York: Garland Publications, 1978, from PhD diss. New York University, 1976); Sidney J. Freedberg, Paintings in Italy: 1500-1600 (Baltimore: Penguin Books, 1993), pp. 117-119; Daniele Radini Tedeschi, Sodoma (Rome: n.p., 1988, 2008 and 2010); Roberto Bartalini, "Giovanni Antonio Bazzi", in Domenico Beccafumi e il Suo Tempo, Alessandro Bagnoli et al. (Milan: Electa, 1990), pp. 228-52, catalogue entries for the exhibition; and Roberto Bartalini, A. Zombardo, Antonio Bazzi, il Sodoma: fonti documentarie e letterarie (Vercelli: Società Storica, 2012).

${ }_{5}^{4}$ See BB Vasari, p. 382; and Cust, Bazzi, pp. 15-16.

${ }_{5}^{5}$ See BB Vasari, p. 385; and Cust, Bazzi, p. 17.

${ }^{6}$ See BB Vasari, pp. 381 and 390.

7 See BB Vasari, p. 390; and Cust, Bazzi, p. 53.

8 See Tedeschi, Sodoma, passim; Carli, Mostra of 1950, passim; and Bartalini, Bazzi, pp. 228-252.
} 
paintings as well as on the patrons for these commissions. Bazzi completed several allegorical or mythological paintings such as an Allegory of Fame of 1510 in the Chigi-Saracini Collection of Palazzo Saracini in Siena (presently lost); Amore Celeste or The Allegory of Celestial Love of 1510, in the Chigi-Saracini Collection in Siena; Terrestrial Lovel and Celestial Love of 1510-15 at the Musée du Louvre in Paris; Cupid of 1510-15, now in a Private Collection; and two versions of The Fates, Parche or Moirai of 1525, one located in the Galleria d'Arte Antica e Moderna of Palazzo Barberini in Rome and the other in the Pinacoteca of Siena. In this essay, I will analyze just two of Bazzi's allegorical paintings: Amore Celeste of 1510, held in the Chigi-Saracini Collection in Siena (Figure 3), and Terrestrial Love and Celestial Love of 1510-15, now at the Musée du Louvre in Paris (Figure 12).

Among Bazzi's patrons were prominent religious orders and families such as the Medici, Pope Leo X (1475-1521) in Rome, Lorenzo di Galeotto de' Medici in Volterra, and the avid artistic patron and banker Agostino Chigi (1466-1520), residing both in Siena and Rome, who commissioned the Stories of Roxanne and Alexander the Great of 1510 for his Roman palace, the so-called Villa Farnesina. Another patron was the eccentric aristocrat and wealthy merchant Pandolfo Petrucci (1452-1512) from Siena, who commissioned in 1509 decorations for his palace, the Palazzo del Magnifico, which had majolica tiles in the pavement from Barili's workshop and walls with frescoed cycles of ancient Roman history and myths painted by Pinturicchio, Genga and Luca Signorelli (1445-1523) - and perhaps Bazzi as well. The Palazzo was dismantled in 1512.9 One of the ceilings is now at the Metropolitan Museum of Art and another at the Victoria and Albert Museum in London. ${ }^{10}$ In the Prince, Book XXII, Niccolò Machiavelli praised Petrucci for being a cautious ruler, who guarded himself against suspicious individuals: "Pandolfo Petrucci, principe di Siena, reggeva lo stato suo più con quelli che li furono sospetti che con li altre". Hence, formulating the saying "keep your friends close but your enemies closer". ${ }^{11}$

\footnotetext{
9 See Giovanni Agosti and Vincenzo Farinella, "Interni senesi all'antica", in Bagnoli, Domenico Beccafumi, pp. 554-599; and Fabrizio Nevola, Siena: Constructing the Renaissance City (New Haven: Yale University, 2007), pp. 196-206. In 1508, Petrucci commissioned Domenico di Bartolomeo to construct his palace and Giacomo Cozzarelli to design the interiors.

${ }^{10}$ See F. Zeri and E. E. Gardner, Italian Paintings. A Catalogue of the Collection of The Metropolitan Museum of Art. Sienese and Central Italian Schools (New York: Metropolitan Museum of Art, 1980), pp. 67-69.

11 "Hanno è principi, e specialmente quelli che sono nuovi, trovato più fede e più utilità in quelli uomini che nel principio del loro stato sono tenuti sospetti, che in quelli che nel principio erano confidenti. Pandolfo Petrucci, principe di Siena, reggeva lo stato suo più con quelli che li furono sospetti che con li altri" (Princes, and especially those who are new, have found more faith and purpose in those men who at the beginning of their governance appeared to be suspicious, compared to those who from the beginning seemed trustworthy. Pandolfo Petrucci, prince of Siena, governed the state with those that were suspicious rather than with the other [group]. See Niccolò Machiavelli, The Prince (1513), trans. N. H. Thompson (New York: Dover, 1992 repred), Chapter 22, "On the Secretary of Princes"; and Nevola, Siena, p. 196, n.1.
} 


\section{Amor Celeste}

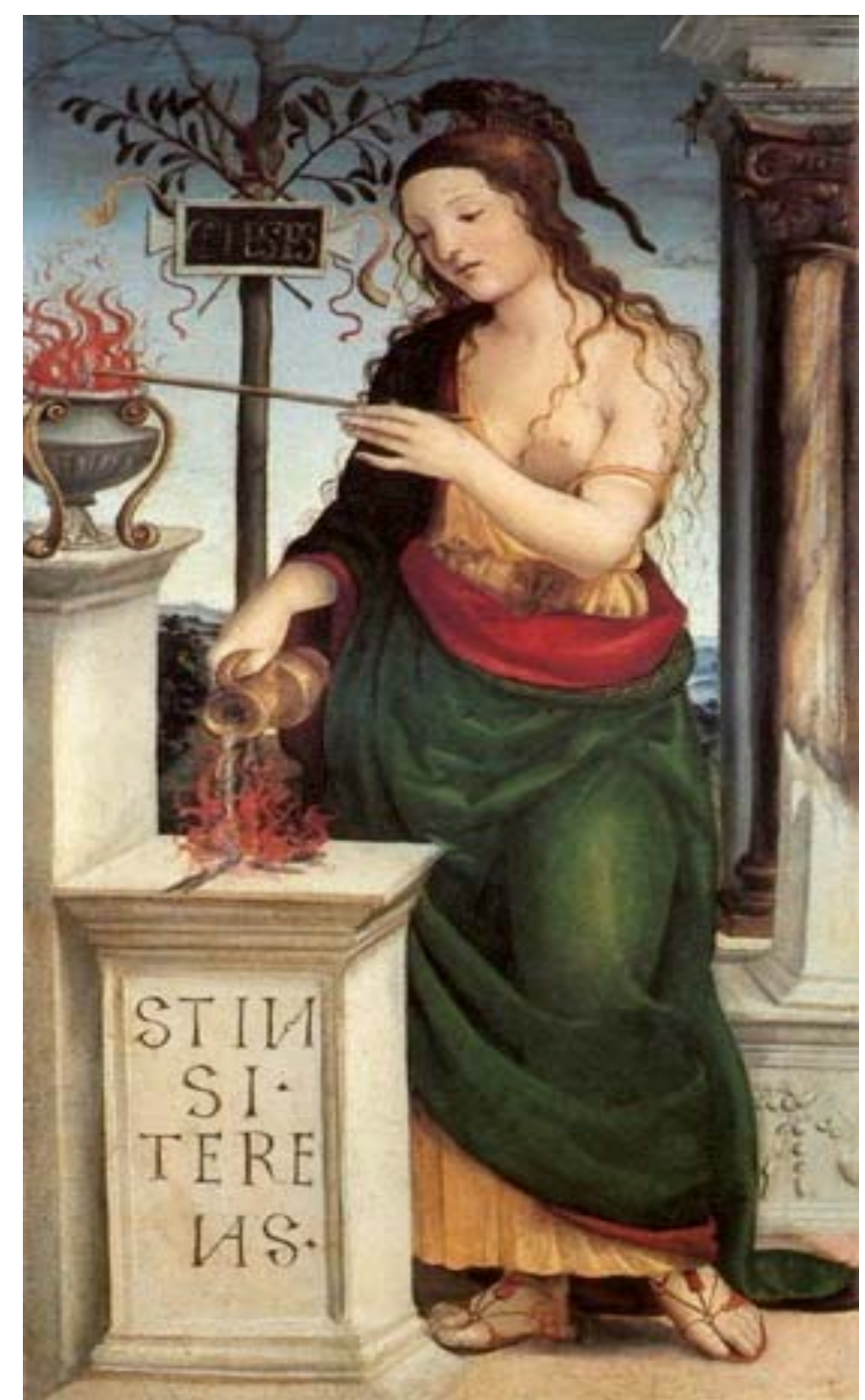

Figure 3. Giovanni Antonio Bazzi, Amore Celeste (Celestial Love), 1510. Chigi-Saracini Collection, Siena.

The wealthy Sienese merchants and promoters of the arts Agostino Chigi or Pandolfo Petrucci likely commissioned Bazzi's Amore Celeste or The Allegory of Celestial Love of 1510, now in the Chigi-Saracini Collection in Siena (Figure 3). Perhaps this allegorical painting was part of a cycle on the virtues, a popular theme represented at this time. ${ }^{12}$ Bazzi's composition consists of two levels: physical and metaphysical. The physical level emphasizes the tangible aspects of nature as seen in the sfumato landscape in the background, while the metaphysical is depicted metaphorically in the foreground. Continuing with this dichotomy, the natural landscape composed of mountains, forest and sky-scape in the background is contrasted with the foreground architectonic frame of an interior loggia, with a classical pilaster, an engaged Ionic column, a fragmented pilaster and marble offering altars. Between landscape and the loggia stands a barren tree, a sycamore tree, whose top branches are decorated with a knot made of a red cloth and two crisscrossed olive branches. A hanging classical cartello with a Latin inscription Celestes, meaning celestial or heavenly, provides

${ }^{12}$ See Bartalini, “Bazzi”, pp. 266-269. 
the title for the painting.

Paralleling the vertical movement of the ancient architectural forms of pilaster and column and the sycamore tree is a standing female. Metaphorically, she separates and balances two aspects in physical realm: the natural and the fabricated. The female is dressed in ancient garments. A yellow chiton both covers and reveals her soft upper body, while a red and green himation wraps around her body, emphasizing her contrapposto stance. Her Roman sandals of red color match the color red of her himation's interior lining. The female figure's long brown tresses are crowned with an ancient Roman helmet. The metal cap of the helmet is enameled with festoons and ribbons of red and green colors like the himation; below the crest of the helmet a small sculpture of a sphinx decorates and contrasts with the rest of the military headdress. Bazzi repeated the same festoon decoration located at the base of the fragmented pier, demonstrating his mastery in depicting various types of materials.

There are three indicators in the painting that assist in decoding the meaning of the imagery: the identification of the mythological female figure and her actions; the Latin inscriptions; and two burning fires on two sacrificial altars.

Several identifications are suggested for this enigmatic female figure in Amore Celeste. She may represent Minerva, Pallas Athena, the Goddess of Wisdom and Artistry; Isis, the Goddess of Magic and Prophecy; or Vesta, the Goddess of Fire. She could represent the Goddess Minerva or Pallas Athena. Having been created from Vulcan, God of Fire, and from the head of Jupiter, King of the Gods, Minerva embodied godliness and the creative forces of fire. Her artistry is not limited to the arts but includes the universal concept of creation. In classical writings, Hesiod in particular noted that Prometheus, after composing a human figure made of clay, asked Pallas Athena to give it life. She breathed a butterfly inside the human form, providing it with a soul. In Amore Celeste, the female figure, when igniting the celestial fire, also becomes an allegory of creation. ${ }^{13}$ Residing in Florence in the early 1500s, Bazzi was probably aware of Botticelli's art, for instance, the Pallas and the Centaur of 1480-85 at the Galleria degli Uffizi (Figure 4). ${ }^{14}$

\footnotetext{
13 See Hesiod, "To Athena", in The Homeric Hymns and Homerica, trans. Hugh G. Evelyn-White (Cambridge, MA: Harvard University Press, The Loeb Classical Library, 1914), pp. 443-55; Christine Downing, The Goddess: Mythological Images of the Feminine (New York: Crossroad, 1984), p. 105, citing Hesiod's passage; and Lewis Richard Farnell, The Cult of the Greek States, 2 vols (Chicago: Aegean Press, 1971), p. 314, alluding to the creative powers Vulcan, Prometheus and Athena.

${ }^{14}$ See Liana De Girolami Cheney, "Botticelli's Interpretation of 'Antiquity': Camilla/Minerva and the Centaur", in Discovery (Spring 2002), pp. 1-14.
} 


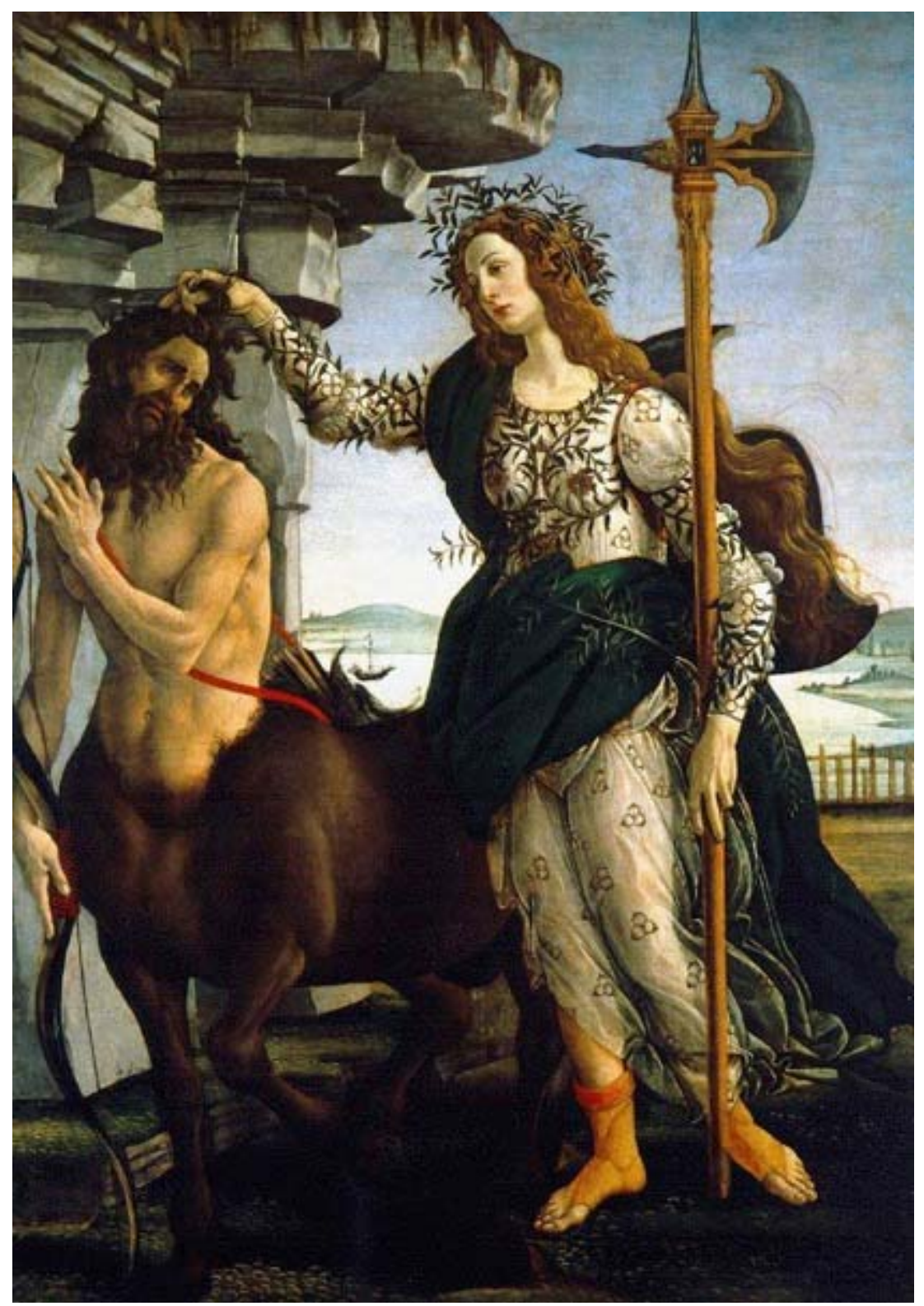

Figure 4. Botticelli, Pallas and the Centaur, 1480-85. Galleria degli Uffizi, Florence.

It is uncertain that he would have seen the painting in the Medici palace, but then he worked for a Medicean Pope, Leo X. Compositionally there are interesting similarities, for example the contrapposto stance in both females, but then it could be a similar classical source - both females have inclined heads and long stresses, the emerald green himation, and the marble pilaster with the intrusive vegetation at the top.

In observing the helmet worn by the figure in Amore Celeste, Bazzi appropriated the design from Renaissance engravings, paintings and sculptural reliefs for the helmet motif, as seen in Andrea Mantegna's Minerva of 1502 in Minerva Expelling the Vices from the Garden of Virtues at Musée du Louvre; in engravings by Marcantonio Raimondi's Pallas Athena of 1510-15, after Raphael or Giulio Romano; in Nicoletto da Modena's Pallas Athena of 1507-10 (Figure 5); and in particular the ancient marble relief of the personification of Roma in the Apotheosis of Antoninus Pius and Faustina located on the pedestal of the Column of Antoninus 
Pius of 161 in Rome (compare Figures 6 and 7).

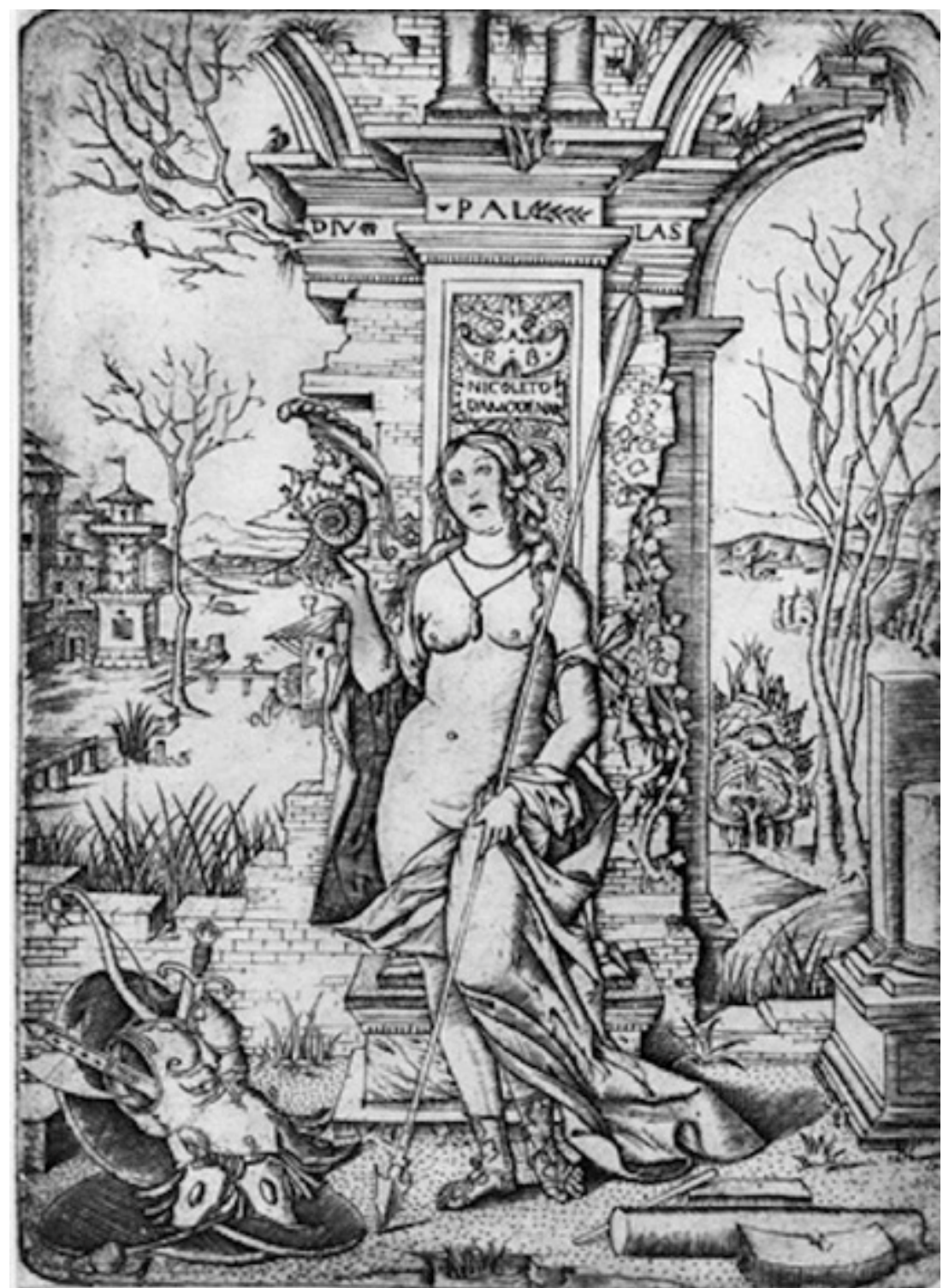

Figure 5. Nicoletto da Modena, Pallas Athena, 1507-10, engraving. Ashmolean Museum of Art and Archaeology, University of Oxford (WA 1863.1754).

While in Rome, Bazzi, enamored with Raphael's art, made drawings of the figure of Minerva from Raphael's grisaille figure of Minerva in the Sala della Segnatura at the Vatican. Bazzi was familiar with ancient Roman mythology; not only had he lived in Rome and seen the Roman ancient ruins but he was also painting a cycle on ancient history about Roxanne and Alexander the Great for Agostino Chigi at his Roman palace. Hence stylistic appropriations from this frescoed cycle are revealed in the painting of Amore Celeste, such as classical architecture, the overall composition of indoor and outdoor space, and the classical pose of the female figure. 


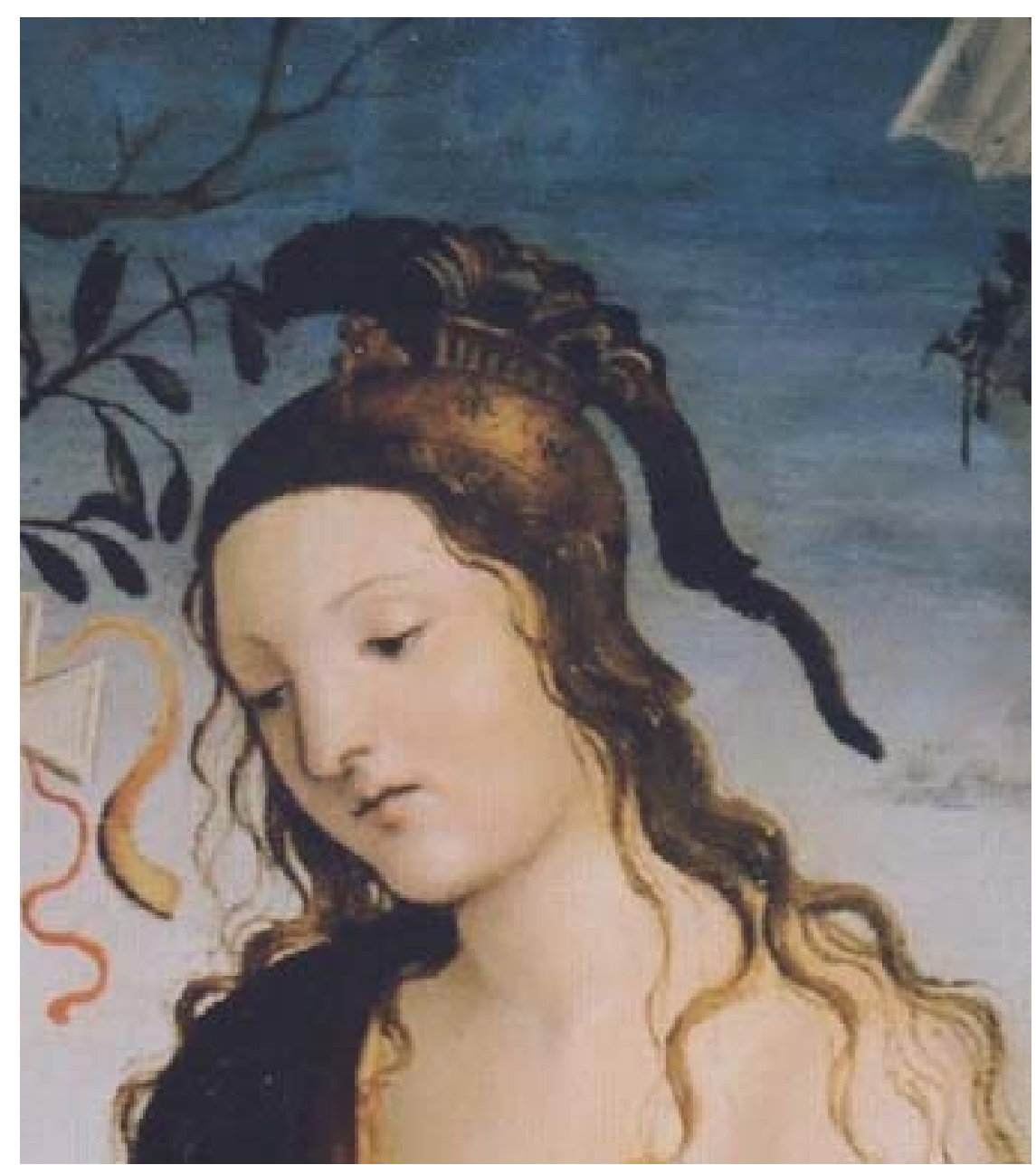

Figure 6. Giovanni Antonio Bazzi, Amore Celeste (Celestial Love), 1510, det. Chigi-Saracini Collection, Siena. 


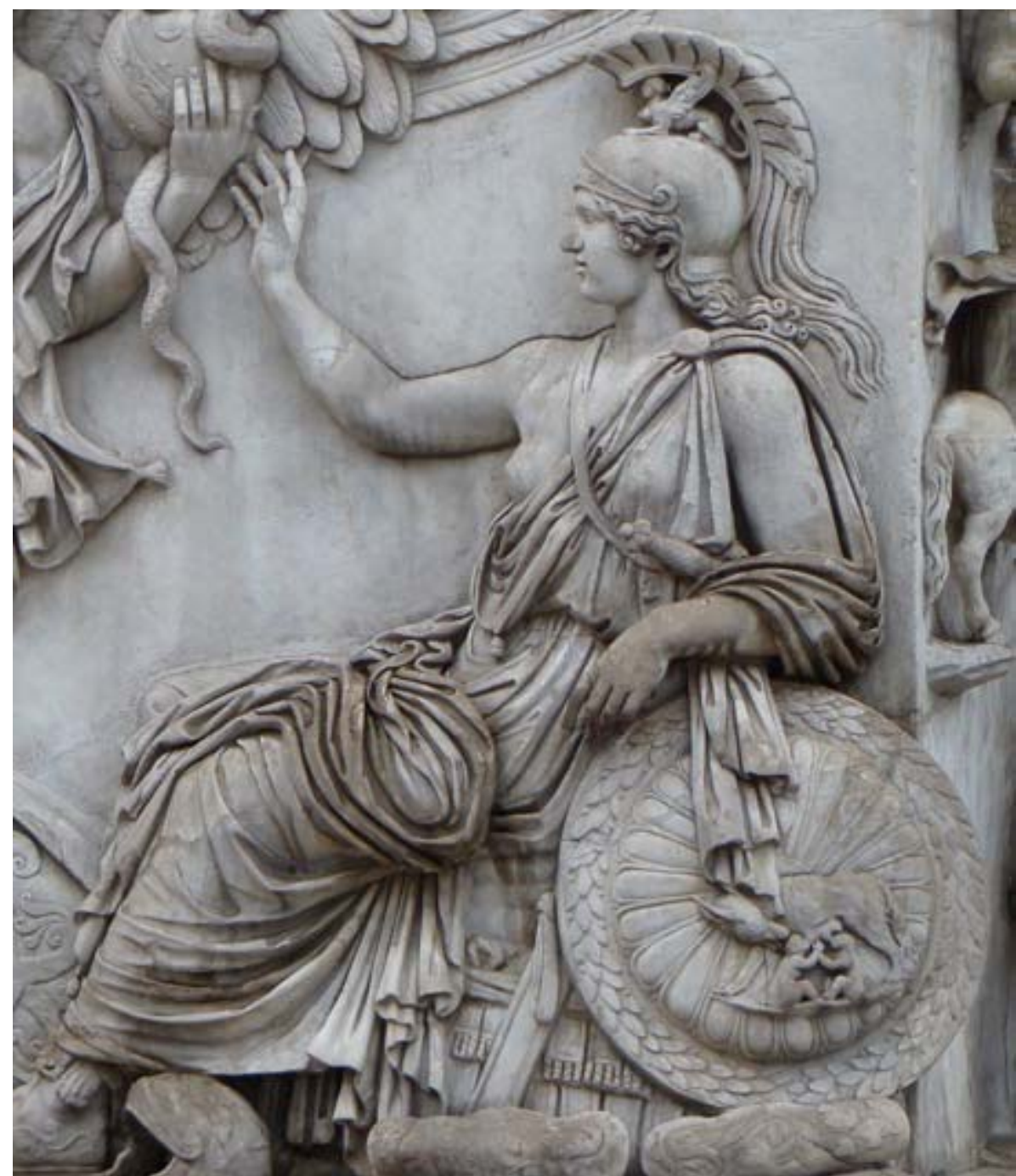

Figure 7. Roma, 161, det., marble relief from the column of the Apotheosis of Antoninus Pius and Faustina, Rome.

Another interpretation is that the figure in Amore Celeste could be a representation of the Goddess Isis. In Egyptian mythology, Isis was considered an ancient deity of Wisdom, Power and Divine Mystery and, specifically, a Goddess of Sacred Magic. ${ }^{15}$ In the Farnese Collection of ancient art in National Archaeological Museum in Naples, a Roman statue of Isis dating to the 2nd century CE holds a vessel of water, symbol of life and purification, and a lotus in her other hand (Figure 8). Her purple attire refers to her royal divinity and its folds reveals the knot of Isis. This type knot is known as tyet or amulet. Comparing the statue's symbolism with Bazzi's Amore Celeste, as mentioned earlier there is a representation of the sycamore tree, which was consecrated to Isis in antiquity. The tree is decorated with a piece of red cloth looped and then knotted around the tree trunk, alluding to its magical powers. ${ }^{16}$ The carnelian color of the knot is associated with the blood of Isis,

\footnotetext{
${ }^{15}$ See M. Isidora Forrest, Isis Magic (Portland, OR: Abiegnus House, 2013), pp. 31-54; and Anne Baring and Jules Cashford, The Myth of the Goddess (Baltimore, MD: Arkana, Penguin Books, 1993), pp. 225-272, on Isis.

16 See P. Remler, Egyptian Mythology A to Z (New York: Chelsea House, 2010), pp. 106-107.
} 
a good omen for the worshiper. ${ }^{17}$ The symbolism of the knot of Isis, tyet, however, reveals two paradoxical ideas: the notion of binding and releasing and the joining of opposites, such as physical versus metaphysical aspects of nature, landscape versus architecture, and fire versus water. ${ }^{18}$

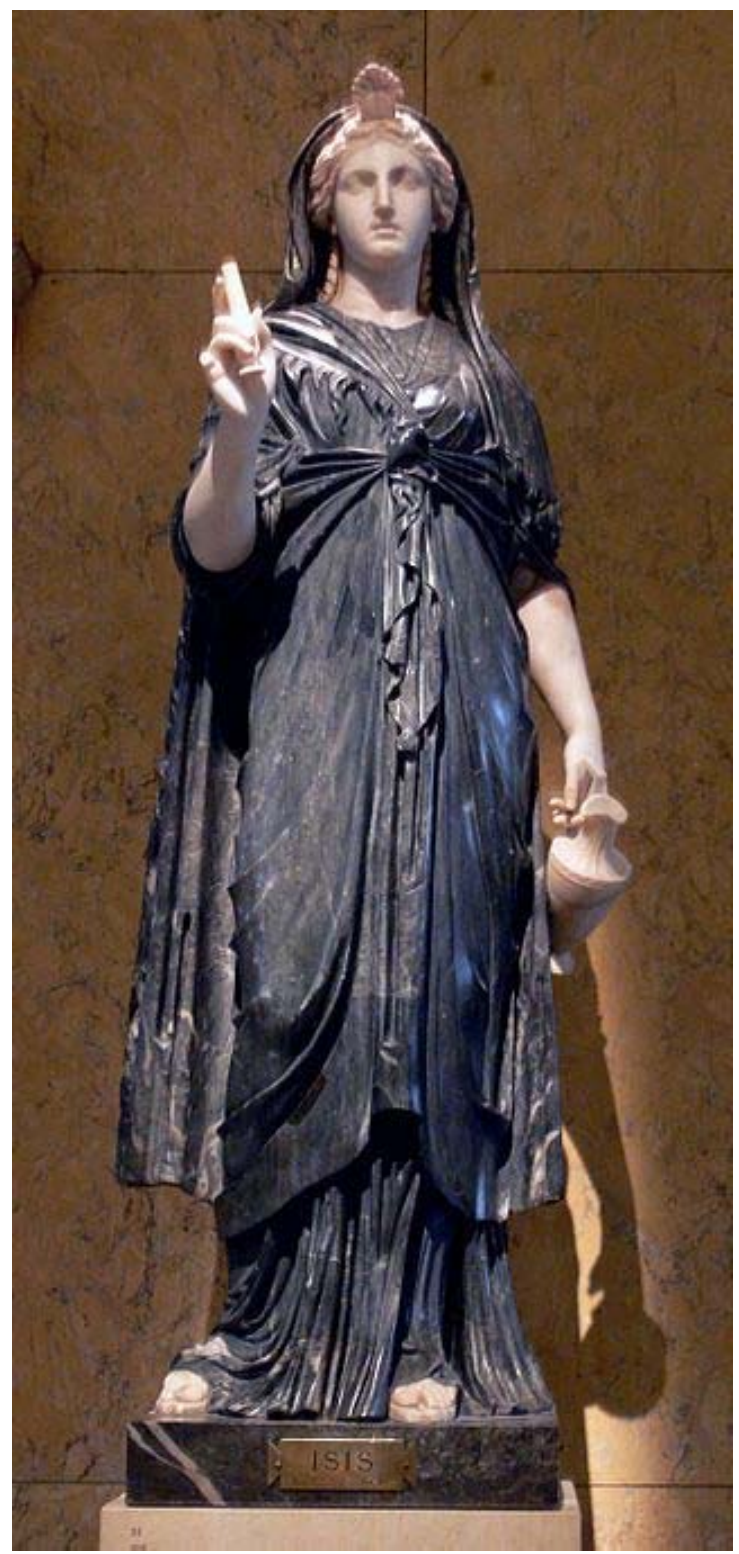

Figure 8. Ancient Roman Statue of Isis, 2nd Century CE. Farnese Collection, National Archaeological Museum, Naples.

\footnotetext{
17 See Remler, Egyptian Mythology A to Z, pp. 106-107. Consistent with the mythological tradition, Bazzi selected the carnelian color, which was associated with the blood of Isis and was a good omen for the worshiper. In a pyramid text a sonnet reads: "Let the blood of Isis and the magical words of Isis be mighty and protect and keep safely. With this special protection from Isis and the tyet amulet, the deceased could travel anywhere in the underworld".

${ }^{18}$ Knot magic was well known in Egypt from an early period, for example, an inscription in one of the pyramids states: "Isis and Nephthys work magic on Thee [Osiris] with knotted cords". See Forrest, Isis Magic, pp. 31-54.
} 


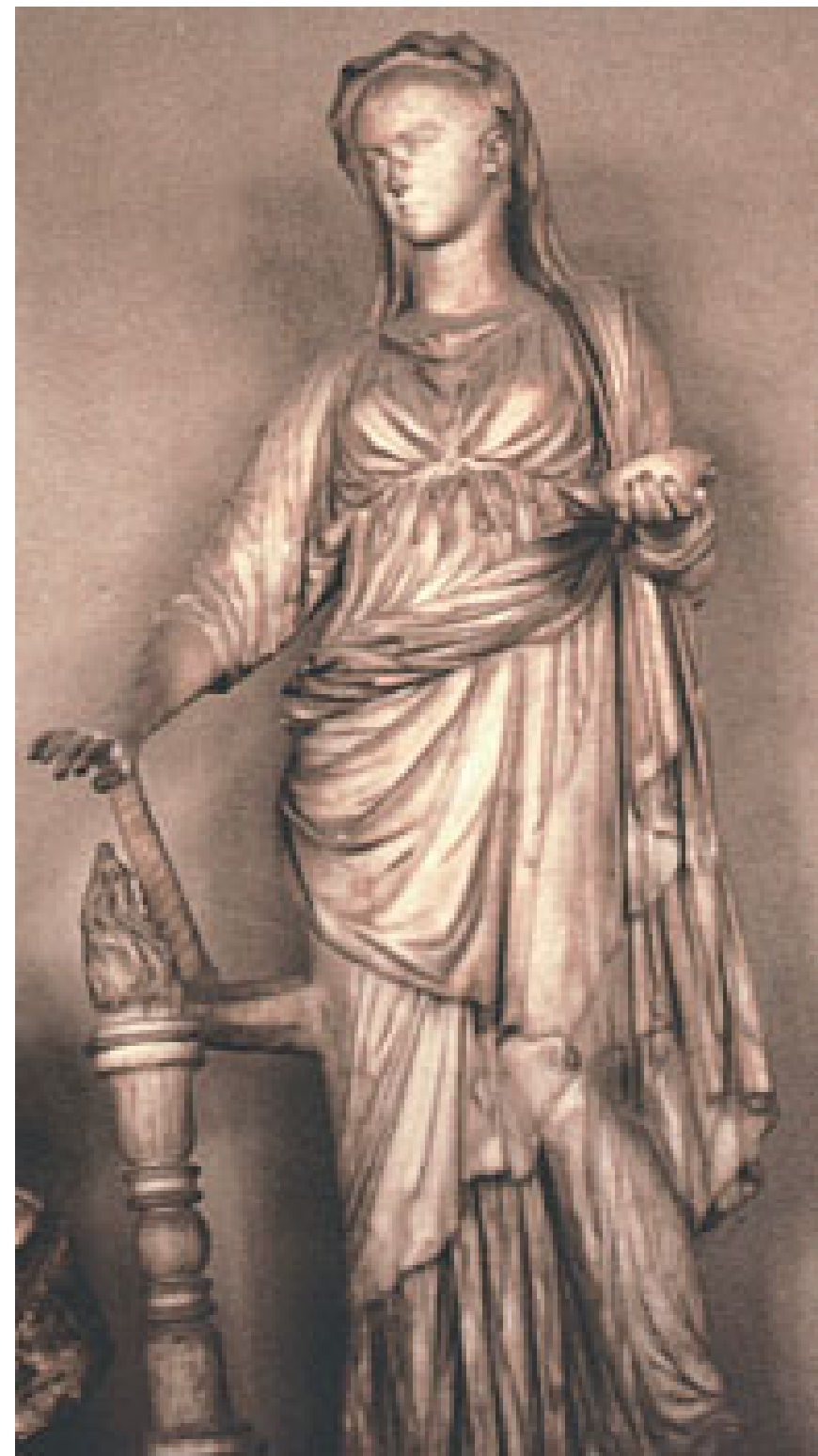

Figure 9. Roman Statue of Vesta with Flame, 1st century CE. Galleria degli Uffizi, Florence.

For the female figure yet another possible identification is with the Goddess Vesta, the Goddess of Fire, Hearth and Purification, as seen in the Roman statue of Vesta with Flame of the 1st century CE, at the Galleria degli Uffizi in Florence (Figure 9). The ancient writers and humanists Marcus Tullius Cicero (106 BCE-43 BCE), Plutarch (45 CE-120 CE) and Marcus Terentius Varro (116 BCE-27 BCE) explained how in Rome the followers of Vesta, the Vestal Virgins, were responsible for protecting the sacred fire of the city, which was never allowed to extinguish. ${ }^{19}$ The allusion of burning fire is part of an ancient tradition for venerating a deity and purifying terrestrial elements, not just in the Temple of Vesta, but also recalls the burning torch of Apollo, Hermes' fire, and the inextinguishable fire in the temple of the Acropolis. Also in biblical iconography, the burning fire had a sacred signification of divine presence and spiritual guidance, as in Moses' burning bush, the burning lamp of

\footnotetext{
${ }^{19}$ See Mary R. Lefkowitz and Maureen B. Fant, Women's Life in Greece and Rome (Baltimore, MD: John Hopkins University Press, 2005), p. 179.
} 
Abraham, and the pillar of fire of Exodus. ${ }^{20}$

Compositionally and thematically, Bazzi's Amore Celeste was also inspired by Nicoletto da Modena's engraving of the Allegory of Victory or the Vestal (Figure 10), which refers to Octavian Augustus's imperial victory in achieving the pax romana and his creation of a celebratory festival to be held every ten years. ${ }^{21}$ The complex visual representation is filled with incongruous vignettes. In the background there is a rural landscape contrasting with a classical loggia in the foreground where a figure is igniting a sacred fire while putting out another. On the baseboard, the engraver's insignia letter " $\mathrm{A}$ " is visible along with the bucrania decorations. The ruins of a temple with an fragmented plinth and one Ionic column with a cracked shaft contrasts with a dormant bare tree that is holding crisscrossed laurel branches and a cartello with the Lain inscription VOTISX. Two sacrificial altars are visible with burning fires; the one ignited by the Vestal Virgin is roaring inside a fanciful sacrificial tripod, while the fire that is being put out with water is burning from wooden sticks resting on the smaller altar. The base frontal panel of this altar contains a long Latin inscription SPE PUB / LICA / PAXAETE / RNA / VICTORIA / AUGUSTI (Roman Hope, Eternal Peace, and Victory to Augustus), a reference to the divine personifications granted by the gods to emperor Augustus to provide a righteous reign. He also was gifted by the gods with individual blessings such as intelligence (mens), virtue (virtus) and faith (fides). The cartello on the tree contains the Latin inscription VOTISX, which is a compound word: VOTIS means vows, and $\mathrm{X}$ is the Roman numeral ten and as such refers to the Roman decennalia, a festival of vows or prayers celebrated upon every ten years of good governance. The decennalia was a festival originated by Augustus in $27 \mathrm{BCE}$, which he requested be honored only every ten years and not in perpetuity. ${ }^{22}$ The VOTIS $\mathrm{X}$ inscription became a popular inscription on Roman coins of emperors such as Antoninus Pius, Diocletian and Maximian, The Allegory of Victory's helmet is decorated with grape leaves that are associated with the Roman festivals and the cult of Bacchus (Dionysus) as a symbol of hope, prosperity and fertility, reinforcing the commemorative meaning of the cartello, VOTISX.

\footnotetext{
${ }^{20}$ See H. P. Blavatsky, Isis Unveiled: A Master-key to the mysteries of Ancient and Modern Science and Theory, 2 vols (Point Loma, CA; The Aryan Theosophical Press, 1919), Vol. I, p. 125, Chapter V.

${ }^{21}$ See Gisèle Lambert, Les Premières gravures Italiennes (Paris: Éditions de la Biblothèque Nationale de France, 1999), pp. 288-311, Entry 553.

${ }_{22}$ See Sarah B. Pomeroy, Goddess, Whores, Wives, and Slaves: Women in Classical Antiquity (New York: Schocken Books, 1995), p. 214.
} 


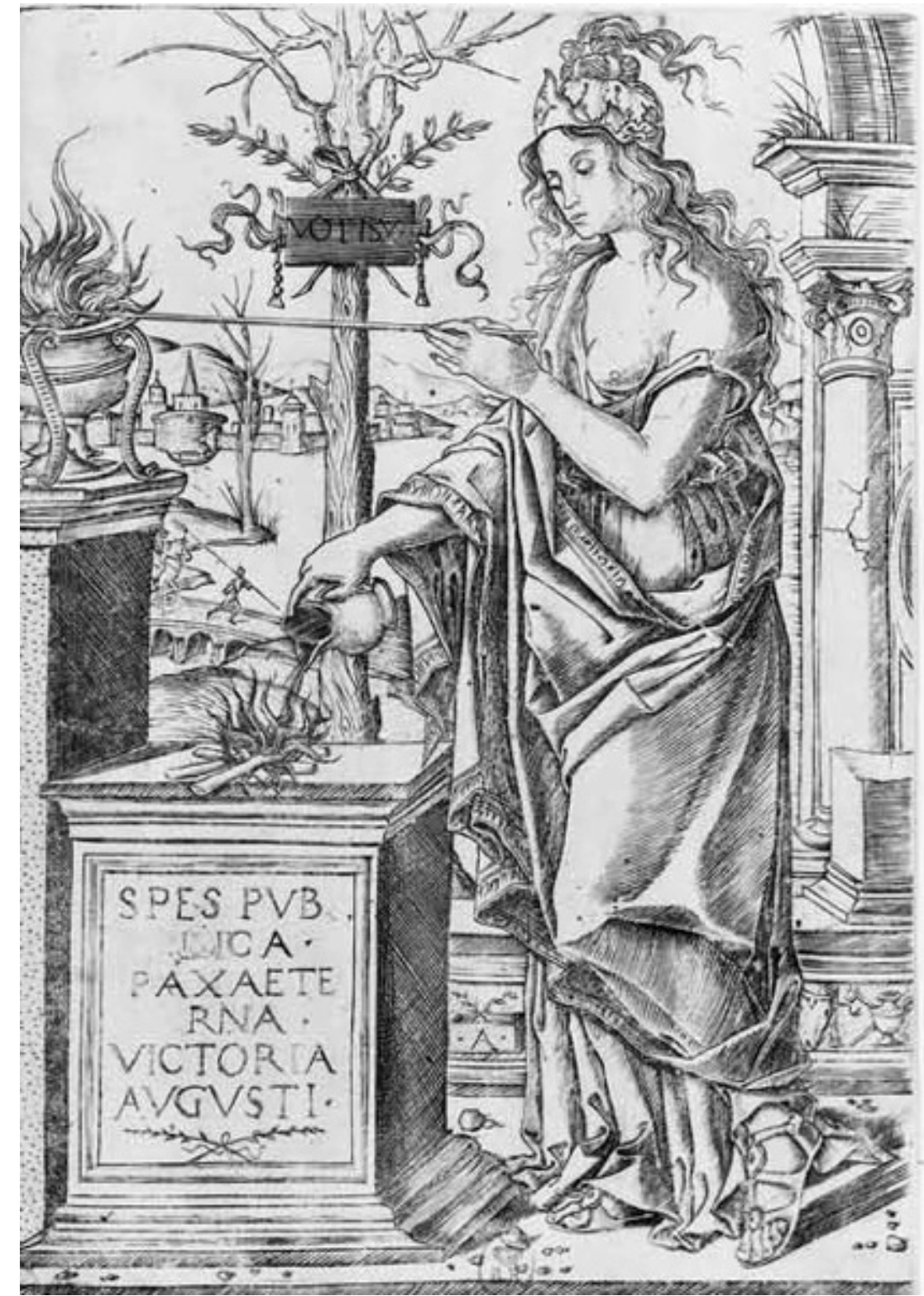

Figure 10. Nicoletto da Modena, The Vestal, 1507-10, engraving, reprinted in G. Lambert, Les Premières gravures Italiannes (Paris: Éditions de la Biblothèque Nationale de France, 1999), Entry 553.

In the Amor Celeste there are two significant puzzling objects: the depiction of the two altars, each holding burning fire, one being ignited and the other being extinguished; and also the meaning of the Latin inscription Stinsi terenas, which translates as: "I extinguish what is terrestrial or I extinguish things that are terrestrial", located on the sacrificial altar.

In classical literature and philosophy, paradoxically, the fire is a symbol of vitality, passion (furor) and victory as well as destruction. ${ }^{23}$ In the third century CE, the Greek founder of Neoplatonism, Plotinus (204-270),

\footnotetext{
${ }^{23}$ In ancient culture and religion, when fire is associated with Vulcan, the God of Fire, it suggests a benevolent action but it is malevolent, when fire is associated with Pluto, the God of the Underworld, Hades.
} 
explained and discussed in his Ennead IV Plato's notion of fire in the Timaeus (31b4-8 lines). ${ }^{24}$ This passage explains Plato's theory about the difference between the celestial fire (stars) and the natural fire (earth), while further elaborating on the physical components of the fire, e.g., the star is composed of pure fire while the fire from earth is composed of mixtures of elements. Thus Plotinus clarified Plato's notions about the element of fire. ${ }^{25}$ Porphyry (234-305), Plotinus' biographer and disciple, refined the meaning of fire, noting that the heaven is made out of fire, which is the dominant element: the fire of the heavens is pure, since it lacks the earthly compositions. ${ }^{26}$ In the fourth century the quest on the signification of fire continued with the Neoplatonist Iamblichus (245-325). In his writings on Theurgia or On the Mysteries of Egypt, Iamblichus claimed that "theurgy was a system of white magic practiced by early Neoplatonists, not simply because of the mechanism of the ritual but because of the foundation of divine love, which supports the process of transformation of the natural elements, such as fire". ${ }^{27}$

As the cult of Isis's dispersed from its origin in Egypt to Greece, Rome and beyond, her identity as Goddess of Magic increased. ${ }^{28}$ "This type of identification was so instilled in the culture that when the Neoplatonic philosopher Plotinus agreed to a magical evocation of his guardian spirit, the Egyptian priest who conducted the ceremony insisted for the event to be performed inside in the Temple of Isis because her temple was the only pure place appropriate for the working of high magic in all of Rome". ${ }^{29}$

Moreover, the Roman poet Apuleius (125-170), in discussing the mysteries of Isis in his novel the Golden Ass or Metamorphoses, also noted that in Rome, from the middle Imperial period, the honorific title Caelestis, "Heavenly" or "Celestial", was associated with several goddesses who embodied supreme heavenly powers, such as Isis, Minerva or Pallas Athena, and Vesta. ${ }^{30}$ This appellation comprised the metaphysical ramifications of divine power and astronomical formations, which meant that the Dea caelestis was identified with the constellation of Virgo (the Virgin) who held the divine balance of justice ${ }^{31}$ it is not by accident depicted in Bazzi's cartello.

\footnotetext{
${ }^{24}$ See Plotinus, Ennead IV-11:16: "What intelligent mind can doubt the immortality of such a value, one in which there is a life self-springing and therefore not to be destroyed? This is at any rate a life not imported from without, not present in the mode of the heat in fire-for if heat is characteristic of the fire proper, it certainly is adventitious to the Matter underlying the fire; or fire, too, would be everlasting - it is not in any such mode that the soul has life: this is no case of a Matter underlying and a life brought into that Matter and making it into soul [as heat comes into matter and makes it fire]". See Michael F. Wagner, ed. Neoplatonism and Nature: Studies on Plotinus Enneads (New York: State University of New York Press, 2002), p. 35.

${ }^{25}$ See Wagner, Neoplatonism and Nature, p. 35.

${ }^{26}$ See Wagner, Neoplatonism and Nature, p. 35.

${ }_{27}$ See John F. Finamore, "Iamblichus on light and the transparent", in H. J. Blumenthal and E. G. Clark, eds., The Divine Iamblichus (Bristol: Classics Press, 1993), pp. 55-64; Alexander Wilder, Iamblichus: Theurgia or On the Mysteries of Egypt, http://www.esotericarchives.com/oracle/iambl_th.htm (accessed August 29, 2007), Part III; and Forrest, Isis Magic, pp. 31-54.

28 See Pomeroy, Goddess, pp. 218-220, on Isis.

${ }^{29}$ See Forrest, Isis Magic, pp. 31-54.

${ }^{30}$ See Lucius Apuleius' Metamorphoses, Book 11:2, Chapter 47; Apuleius, The Golden Ass, trans. E. J. Kenny (Baltimore, MD: Penguin Books, 1998); and Robert Karl Bohn, "The Isis Episode in Apuleius”, The Classical Journal 68 no. 3 (Feb.-Mar., 1973), pp. 228-31.

31 See Harold Tarrant, "Shadows of Justice in Apuleius' Metamorphoses", in Hermathena 167 (Winter 1999), pp. 71-89.
} 


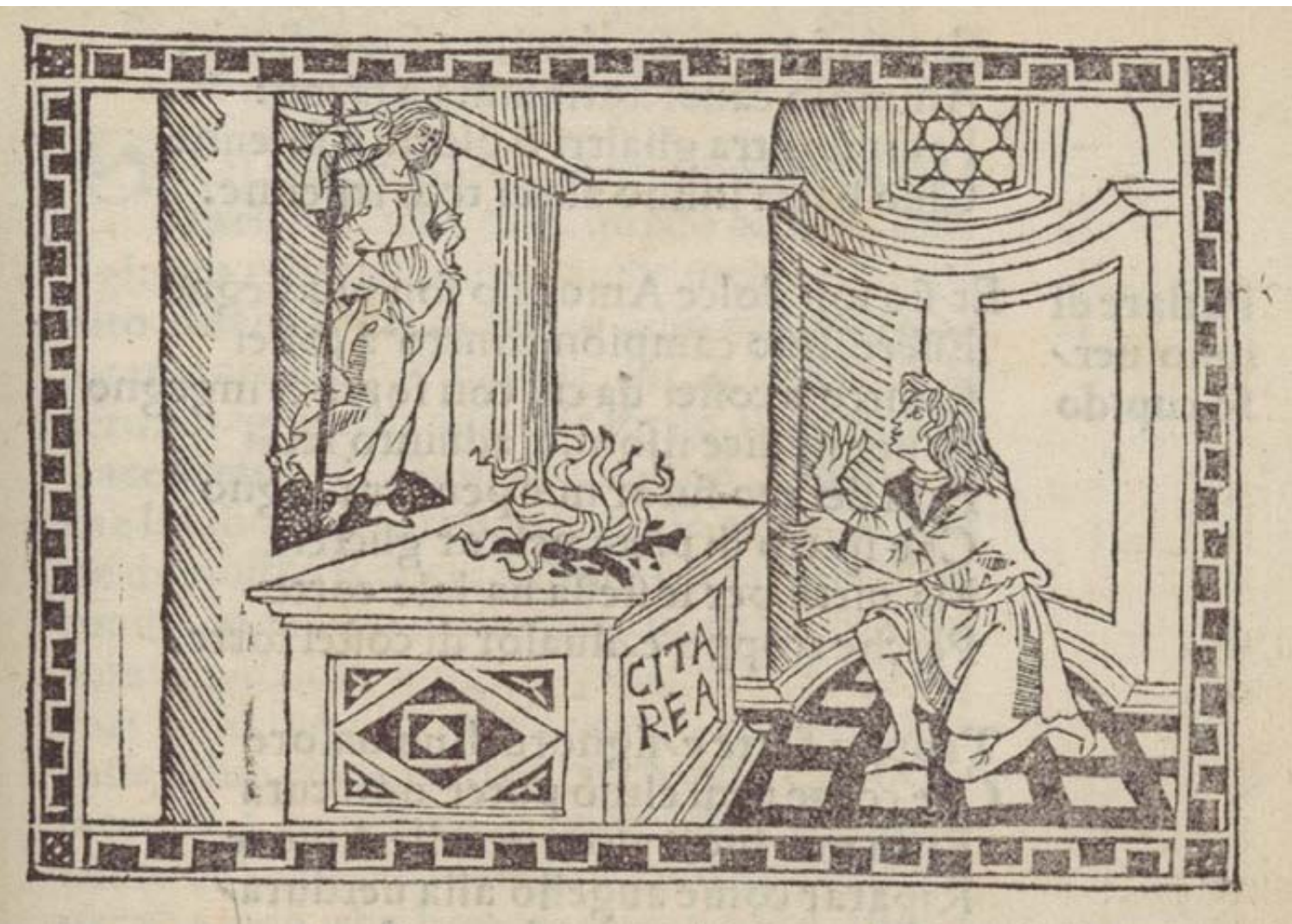

Figure 11. Giulio de' Medici Praying to Pallas (Minerva), from Agnolo Poliziano, Stanze per La Giostra (Florence: Lorenzo de Alopa, 1495/1500).

Bazzi's cultural patronage and travels connected him with the Florentine, Sienese and Roman courts and their intelligentsia circle as well as acquainting him with renown humanists and their ideals, such as the literato Agnolo Poliziano (1454-1494). In one of his poems for the Stanze dedicated to Giuliano de' Medici (1453-1478), there is an illustration showing Giuliano making a sacrifice to the Goddess Minerva on an altar where a flaming fire is visible (Figure 11). ${ }^{32}$ Sienese artists working in Rome, such as Pinturicchio, were also a source of guidance for Bazzi. Pinturicchio's fascination for depicting Egyptian mythology was revealed in the Borgia Apartments of Pope Alexander V of 1494 at the Vatican, and also in the Piccolomini Library of Pope Pius II of 1502-08 in Siena.

In his book on The Egyptian Renaissance, ${ }^{33}$ Brian Curran eloquently addressed the impact of Egyptian hieroglyphs, emblems and mythology on the classical scholars in the erudite circles of the Medici, Farnese and d'Este families. These scholars included the Neoplatonic philosopher and physician, Marsilio Ficino

\footnotetext{
32 See Agnolo Poliziano, Stanze per La Giostra. La Giostra di Giuliano de Medici (Florence: Antonio Tubini printer and Lorenzo de Alopa publisher, 1495-1500), n.p. The image above the poem represents Giulio Praying to Pallas (Oratione di Iulio a Pallade). Book is located at the Metropolitan Museum of Art was gifted by Harris Brisbane Dick Fund in 1925 (Acc. No. 25.30-22). In the printed image one sees the interior of a Roman temple and a niche with a sacrificial altar. The alcove in the niche contains a standing statue of peaceful Minerva, who holds no helmet or shield. The sacrificial altar contains a flaming fire combusted by wooden branches-a terrestrial fire as seen in Amore Celeste. Kneeling and praying at the altar is Giulio, who seeks spiritual assistance from Minerva for his inflamed heart-his furor amorous. The end of stanza reads: [Tu] "Che valorisi cuori a virtú infiammi: Soccorrimi or, Tritonia, e virtú dammi”.

${ }_{33}$ See Brian Curran, The Egyptian Renaissance: The Afterlife of Ancient Egypt in Early Modern Italy (Chicago, IL: University of Chicago Press, 2007), pp. 107-132, 189-227; and on Marsilio Ficino, pp. 97-99.
} 
(1433-1499), who translated the Greek writings of Plato and the Neoplatonists, ${ }^{34}$ the Venetian literary theorist poet Pietro Bembo (1470-1547), and the classicist Giovanni Sulpizio of Veroli (1440-1508), who translated Vitruvius' De architectura. ${ }^{35}$ Furthermore, the publications of the Aldus Manutius press in Venice of emblematic and mythological books, such as Francesco Colonna's Hypnerotomachia Poliphili of $1499^{36}$ further enriched thematically and metaphorically the visual representations of the artists of the Cinquecento, as demonstrated in Bazzi's Amore Celeste.

The Latin inscription in the smaller altar of Amore Celeste is the clavis interpretandi of the painting: Stinsi terenas, which can be translated to mean: "I extinguished earthly [fire]" or "I extinguish terrestrial [things]"or "I extinguish what is terrestrial or I extinguish things that are terrestrial". The Goddess, a fusion of deities Minerva, Isis or Vesta, with her pitcher of water puts out the fire composed by natural materials, in this case burning tree branches, hence a physical realm. This type of water pitcher is traditionally represented in classical funerary or sacrificial altars, e.g., the base altar with festoons and bucrania of the 1st century CE at the Bargello Museum in Florence. Symbolically, the act of extinguishing of the fire alludes to placating consuming terrestrial or human passions (furors). This type of furor was defined and explained by the ancient philosopher Plato in the Phaedrus. He expounded his notion of furor poeticus (divine frenzy) in four categories: poetical, mythical, prophetic and amorous. ${ }^{37}$ In the Renaissance, the Florentine philosopher and physician Marsilio Ficino paraphrased and elaborated on Plato's furors in his writings, De amore (On Love), Commentary on Plato's Symposiumon Love, 1484) and De vita coelitus comparanda (Three Books of Life, 1489). ${ }^{38}$

The second altar in the painting is raised up on a tall pier, on of which top there is a metal urn or sacrificial tripod with a flaming fire, which burns steadily. The metal holder of the fire alludes to its safe and constant burning, as an eternal flame. The goddess, to ensure perpetual fire and eternal love, ignited this fire. ${ }^{39}$ This type of burning fire is divine, being part of the celestial or metaphysical realm, as the cartello hanging from the tree indicates, Celestes, that this fire was created by a celestial being or divinity. Further confirmation of this celestial figure being infused with prophetic powers and divine intelligence is indicated on her decorated metal helmet crown with a crest of plumes whose clasp is decorated with a sculpted sphinx similar to the Roman helmet of the

\footnotetext{
${ }^{34}$ See Marsilio Ficino, Sopra lo amore: Ovvero Convito di Platone (De Amore), ed. and trans. Giuseppe Rensi (Milan: SE SRL, 2003), pp. 17-18; Christine Raffini, Marsilio Ficino, Pietro Bembo, Baldassare Castiglione: Philosophical, Aesthetic, and Political Approaches to Renaissance Neoplatonism (London: Peter Lang, 1998), passim.

35 Between 1486 and 1490, he edited a version of Vitruvius' De architectura (Rome: Eucharius Silber, ca 1487). As a humanist in the Farnese household, he was also the tutor of the young Alessandro (1468-1549).

${ }^{36}$ See Francesco Colonna, Hypnerotomachia Poliphili: The Strife of Love in a Dream, ed. Joscelyn Godwin (London: Thames and Hudson, 2003).

${ }^{37}$ See Michael J. B. Allen, Marsilio Ficino and the Phaedran Charioteer (Los Angeles, CA: University of California Press, 1981), pp. 339-439; and Michael J. B. Allen, The Platonism of Marsilio Ficino (Los Angeles, CA: University of California Press, 1984), pp. 41-67, for a reference to the four types of divinus furor in Ficino's writings, in particular, in his Commentary on Plato's Symposium (7:14): "Quatuor ergo divini furoris sunt speties. Primus quidem poeticus furor, alter mysterialis, tertius vaticinium, amatorious affectus est quartus" (The four divine furors are first poetical, then mythical, third prophetic and amorous fourth).

${ }^{38}$ Ficino wrote a letter to Peregrino Agli on November 29, 1457, where he explains what is furor poeticus or De divino furore (On divine frenzy). See Paul Oskar Kristeller, ed., The Letters of Marsilio Ficino, 3 vols (New York: Ginko Press, 1985), I:14-20; Marsilio Ficino Commentaries on Plato, trans. and ed. Michael J. B. Allen, 2 vols (Cambridge, MA: Harvard University Press, 2008), passim.

39 See Arthur Edward Waite, The Hermetic and Alchemical Writings of Paracelsus (Whitefish, MO: Kessinger Publishing, 2005, repr. 1910). According to Paracelsus (1493-1541), a German Renaissance, physician, alchemist and astrologer, alchemically metal is formed by fire, which includes balanced proportions of sulfur, which makes the fire, mercury, which creates the smoke, and salt, which is the residual of the ashes. These three matters - sulfur, mercury and salt - are known as the three primes (tria prima). See Paracelsus, De Origine Morborum ex Tribus Primis Substantiis (1535?), Paramirum, Lib. 1, c.1.; Part I, First Canon, as illustrated in Bazzi's painting.
} 
personification of Roma (compare Figures 6 and 7). In Renaissance iconography the sphinx is a symbol of prophetic intelligence and mystery because it was associated with Minerva, the Goddess of Wisdom. ${ }^{40}$ Ficino's follower, the Platonist and Kabala philosopher, Giovanni Pico della Mirandola (1463-1494) referred to the sphinx as a "veiled enigma and a poetical concealment" in his book on The Oration on the Dignity of Man. ${ }^{41}$ Although Bazzi appropriated Nicoletto's imagery and conflated the iconographic symbolism of previous Renaissance humanist, painters and philosophers, Amore Celeste remains a delightful enigma.

\section{Terrestrial Love and Celestial Love}

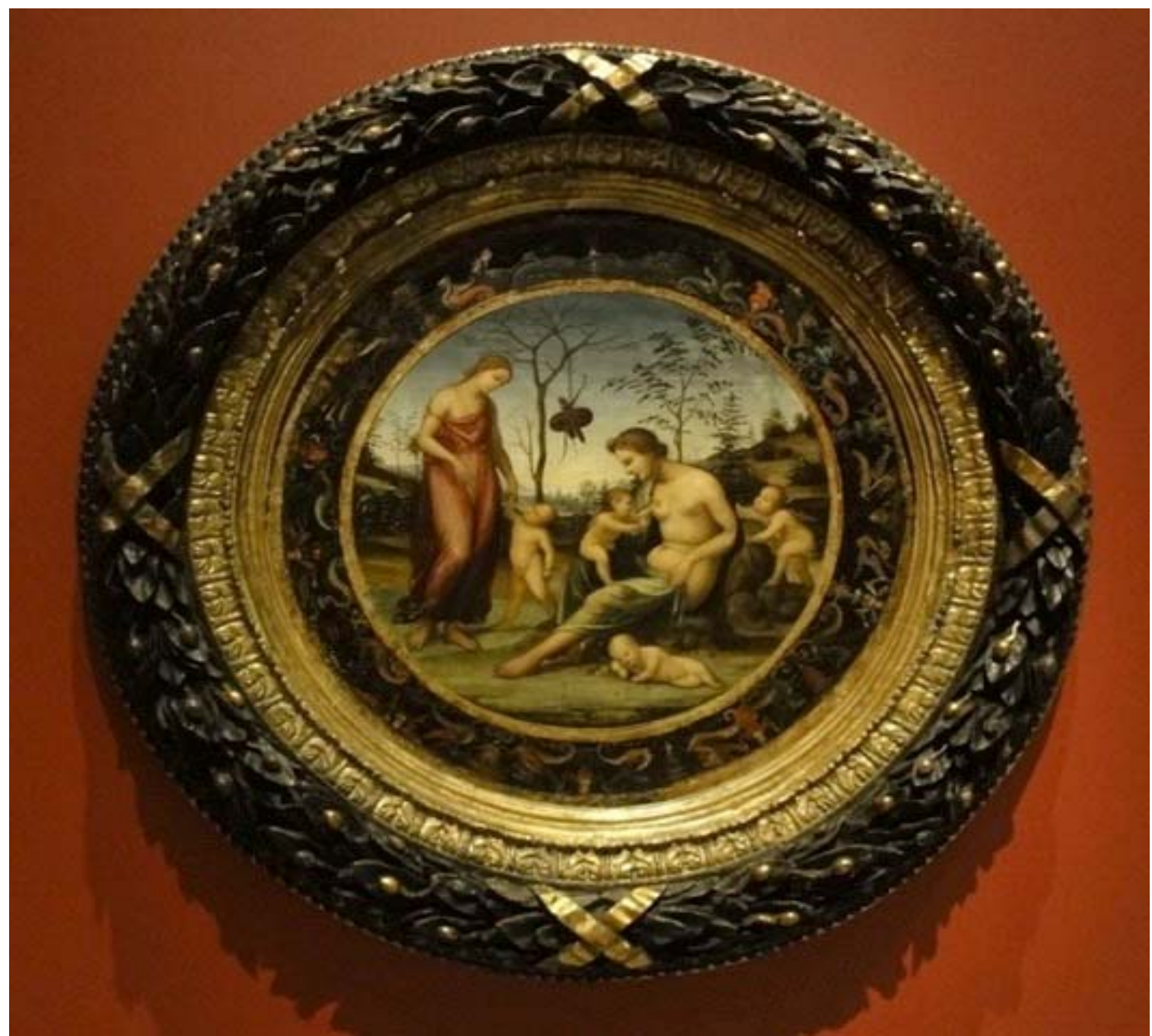

Figure 12. Giovanni Antonio Bazzi, Terrestrial Love and Celestial Love, 1509-11. Camondo Collection. Musée du Louvre, Paris.

\footnotetext{
${ }^{40}$ See Selim Hassan, The Great Sphinx and its Secrets (Cairo: Government Press, 1953), n.p., on the sphinx and antiquity; and Michael Greenhalgh, Donatello and His Sources (London: Duckworth, 1982), pp. 148-56, on the association of the sphinx to the throne of wisdom.

${ }^{41}$ See Giovanni Pico della Mirandola, De hominis dignitate (1486, pub. 1496), citation from the Lebensbeschreibung, 1567 edition; p. 35; Eugenio Garin, ed., Giovanni Pico della Mirandola. De hominis dignitate (Florence: Vallecchi, 1942), p. 581; and André Chastel, "Note sur la Sphinx à la Renaissance", Archivio di Filosofia, Organo dell'Istituto di Studi Filosofici (Rome: Università di Roma, 1958), p. 180, on Pico's comments about the sphinx.
} 
Some art historians have entitled Bazzi's Terrestrial Love and Celestial Love with a variety of titles: for Cust it was Caritas; for Carli, Allegory of Love; Hayum, Two Venuses; and today Louvre's entry refers it with the long title Terrestrial Venus with Eros and Celestial Venus with Anteros and Two Other Cupids. In this essay, I will refer to the painting as Terrestrial Love and Celestial Love (Figure 12). The painting was completed between 1509 and 1511. In the inventories of the Palazzo Chigi in Siena, there is a puzzling notation, which might refer to Bazzi's painting, "An ovato [oval or round] with a woman and four surrounding babies" or it may suggest Domenico Beccafumi's Charity with Four Putti of 1511, at the Victoria and Albert Museum in London. ${ }^{42}$

Bazzi's Terrestrial Love and Celestial Love combines two aspects of love: the profane and the sacred. Perhaps this painting, like Amor Celeste, was commissioned by Agostino Chigi or Pandolfo Petrucci and was part of a cycle on the virtues. ${ }^{43}$ The painting was originally in the Palazzo Chigi in Siena. At an unknown date it was owned by Count Aleksei Bobrinsky (1852-1927), a Russian historian residing in the Villa Malta in Rome. In 1911, it became part of the Schlichting Collection in Paris. Later in time it was part of the Camondo Collection. At an unknown date it was gifted it to the Musée du Louvre as part of their holdings in the decorative arts. ${ }^{44}$

The painting is in the shape of a tondo (round), which suggests a commission for a commemorative gift for a celebratory event. A tondo shape is usually associated with an Italian type of painting called adesco da parto (a birth tray or salver) or a congratulatory marriage gift. Conventionally, the theme for a desco da parto was about children; as a marriage gift a tondo was about a triumph of love, as seen in tondi created during the Renaissance, e.g., Botticelli's Madonna of the Magnificat of 1485 and Michelangelo's Doni Tondo of 1506/08, both at the Galleria degli Uffizi. ${ }^{45}$ Traditionally, these birth or marriage objects, after their use, if any, were hung in a bedroom as a commemorative remembrance. Bazzi's large circular painting with the subject matter of the triumph of love suggests a marriage tondo for a special wedding commemoration, perhaps Petrucci's son, Borghese, who married Vittoria Piccolomini on September 22, 1509, coincidentally the same date of Bazzi's painting. ${ }^{46}$

\footnotetext{
42 See Carli, Sodoma, p. 16; and from the entry posted by the Victoria and Albert Museum, CAI.165: "The Beccafumi's painting was bequeathed by Constantine Alexander Ionides. The tondo was cut down and probably originally formed part of a piece of painted furniture. The main figure represents Charity and was likely originally accompanied by roundels representing the two other theological virtues of Hope and Faith. Beccafumi's Charity is wearing a red dress (with yellow in the highlights) and suckling a child at her breast, an allusion to Charity's provision for the needy. The three playful children may be an allusion to a part of the epistle: 'When I was a child, I talked like a child, I thought like a child, I reasoned like a child. When I became a man, I put childish ways behind me' (1Cor. 13:11)".

${ }^{43}$ According to the records of the Musée du Louvre, the painting came from the Chigi Palace in Siena. I am grateful for the assistance of Denise Agostini in contacting the Conservation Department of the Louvre for information regarding the condition of the tondo in January 2017. The report informs that the painting is in fairly good condition. "Some overall abrasion here and there, a few scratches on the lower left. The frame of the tondo is original as well as the black background borders of the grotesques. The tondo, without the frame, measures $59 \mathrm{~cm}$ in diameter".

${ }^{44}$ See Cust, Bazzi, p. 102; Ettore Romagnoli, Cenni storico-artistico di Siena e suoi suburbi (Siena: Onorato Porri, 1840); n.p.; Ettore Romagnoli, Biografia, cronologia de' bellartisti Senesi dall secolo XII e tutto il XVIII, 12 vols (Siena: Biblioteca Senese, 1835, reissued by Florence: S.P.E.S., 1976), V, p. 720, for a description of the painting in Palazzo Chigi, as "an ovato with a woman and four surrounding babies"; and Maria Teresa, Il Sodoma (Messina: d'Amico, 1951), p. 9. For the history of the provenance, see Cust, Bazzi, p. 102; and Hayum, Il Sodoma, pp. 132 and 134.

45 See A. W. B. Randolph, "Gendering The Period Eye: Deschi da Parto and Renaissance Visual Culture", in Art History 27 (2004), pp. 538-562.

${ }^{46}$ See Nevola, Siena, p. 198 and n. 14; and Andrea Bayer, ed., Art and Love in Renaissance Italy (New York: Metropolitan Museum of Art, 2009), for a discussion on the marriage rituals and ceremonial love gifts, such as cassoni (hope chests), spalliere (head boards), paintings, jewelry and other material goods.
} 
The tondo of Bazzi's Terrestrial Love and Celestial Love is composed of several circles. ${ }^{47}$ The exterior circle, which forms the frame with an elaborate festoon of olive branches intertwined with four golden crisscrossed ribbons, accentuates the cardinal points of the painting, north, west, south and east, recalling the relief festoons in Roman bucrania decorations, for example the Ara Pacis, an altar dedicated to Pax, the Roman goddess of Peace, in 9 BCE in Rome. The second circle is composed of a wide band of gold foliage and bead decorations. While the first and second circles are part of the frame, the third circle is part of the painting's ornamentation. On a black background, elaborate grotesques with urns, winged figures, sphinxes and griffins or dragons are painted with bright green, gold, red and orange colors; this chromatic rainbow is carried over into the imagery inside the painting. Bazzi appropriated the grotesque decorations composed by Pinturicchio between 1502 and 1509 on the ceiling of the Piccolomini Library in the Duomo of Siena for Pope Pius II and from Nicoletto da Modena's engravings of grotesques in an ornamental panel of 1500-10, now at the British Museum in London. Both Bazzi and Nicoletto had traveled to Rome and were inspired by the classical and grotteschi decorations. Nicoletto even visited the Golden House of Nero in 1507 and inscribed his name for posterity on one of the walls. ${ }^{48}$

Inside the tondo composition, Bazzi unveiled a love theme and provided a clue or clavis interpretandi for the viewer by dangling from a barren tree the visible instruments of Amor (Eros/Cupid): a red shield, a bow with a broken string, and a quiver with arrows. This hanging motif is similar to types of themes on Amor depicted in Roman mosaics, for example Psyche and Eros of the $3^{\text {rd }} \mathrm{CE}$, an Imperial Rome mosaic in the Museum Collection of Hatay, Archaeology Museum in Antakya (Antioch), Turkey, and in the decorations of a cartello announcing the theme of the painting as noted in previous Bazzi's paintings such as Amore Celeste.

In Bazzi's painting, the viewer recalls Erwin Panofsky's description of a paysage moralizé, where in a landscape the juxtaposition of barren and blooming vegetation incorporates a moral significance: a landscape incorporating symbols of love, e.g., the antithesis between pleasure and virtue or between profane love and sacred love, which are inherited in natural formations. ${ }^{49}$ If an imaginary vertical axial line is drawn in the composition, two types of love are personified: profane and sacred, but as a unifying composition they personify the theme of the triumph of love. In this allegory of Terrestrial Love and Celestial Love, Bazzi created two levels of conceits: one in the physical realm and the other in the metaphysical. The physical realm, relating to the sensory world, emphasizes the tangible aspects of nature as seen in the sfumato landscape in the background. Within this physical realm, there is a further contrast between a dormant or barren terrain versus a fertile and blooming ground.

The metaphysical realm deals with the intellectual or intelligible world, composed metaphorically with the group of figures in the foreground. Continuing with this dichotomy, the natural landscape composed of

\footnotetext{
${ }^{47}$ However, the tondo decoration is very similar to the ornamentation seen in the center of the ceiling of the Palazzo il Magnifico in Siena. In both representations the large floral decorations with fastened ribbons mark the four cardinal points.

${ }^{48}$ See Deanna Petherbridge, "Graphic Intersections: Erga, Parerga and Pro-Erga", in Journal of the International Association of Research Institutes in the History of Art (March 2014), pp. 83-98 (Special edition on Art History and Design); Gisèle Lambert, Les Premières gravures Italiannes (Paris: Éditions de la Biblothèque Nationale de France, 2015), on Nicoletto da Modena; Arthur Mayger Hind, Early Italian Engraving: A critical catalogue with complete reproductions of all the prints described, 5 vols (Centre, CT: Martino Pub, 2006), V: Marcantonio and Italian engravers and etchers of the sixteenth century, including Nicoletto da Modena.

49 See Erwin Panofsky, Studies in Iconology (New York: Harper and Row, 1967), p. 64, for a definition of paysage moralisé: "Where in a landscape Virtue and Pleasure are symbolized by the contrast between an easy road winding through beautiful country and a steep, stony path leading to a forbidding rock"; and Patricia Emison, "The Paysage Moralisé", Artibus et Historiae 16, no. 31 (1995), pp. 125-137.
} 
landscape, cityscape and sky-scape of Siena in the background is contrasted with the composition of human personifications in the foreground. Bazzi crystalized his conceit with the depiction of Amor's instruments of love, suggesting another physical and metaphysical metaphor in the painting.

The interplay of the dichotomy in the realms becomes a complex bond among the types of love at physical and metaphysical levels; this refers to Renaissance Neoplatonic conceits: (1) human/profane love versus spiritual or sacred love (agape); (2) mythological love or the erotic love of Eros versus the intellectual love of Anteros; (3) and philosophical love in the realms of Venus Humanitas (Terrestrial Venus or Natural Venus) versus Venus Urania (Heavenly Venus or Celestial Venus). ${ }^{50}$ Bazzi’s familiarity with these types of ancient and Renaissance Neoplatonic concepts are culturally and visually appropriated from his study of antiquity during his travels to Rome, and from observing the visual representations of his Sienese fellow artist, for example, Pinturicchio's decorations in the ceiling of the Piccolomini Library of 1502 and on the floor mosaic of the Allegory of the Hill of Wisdom and Fortuna in the Siena Cathedral of 1504, and Giovanni di Stefano's mosaic decoration of Hermes Trismegistus of $1500 \mathrm{~s}$ in the pavement of the Siena Cathedral. ${ }^{51}$ Bazzi had also access to the rare collections and libraries of the Chigi, Piccolomini and Petrucci families, which facilitated his artistic conceits, in particular the library of Niccolò Borghesi, father in law of Petrucci, which contained books by the Renaissance Neoplatonic philosopher and physician Marsilio Ficino. ${ }^{52}$

\footnotetext{
50 See Liana De Girolami Cheney, Botticelli’s Neoplatonic Images (Potomac, MD: Scripta Humanistica, 1993); pp. 33-36; André Chastel, Marsile Ficin et L'Art (Geneve: Droz, 1975), p. 119; and Michael J. Allen and Valery Rees, eds, Marsilio Ficino: His Theology, His Philosophy, His Legacy (Leiden: Brill, 2002), pp. 327-28.

${ }^{51}$ In 1460 a copy of the Hermetica was purchased by Lorenzo de' Medici and translated by Ficino, see Edith Balas, Michelangelo's Medici Chapel: A New Interpretation (Philadelphia, PA: American Philosophical Society, 1995), Vol. 216 , p. 34.

${ }_{52}$ See Keith Christiansen, ed. Painting in Renaissance Siena, 1420-1500 (New York: The Metropolitan Museum of Art, 1998), p. 57.
} 


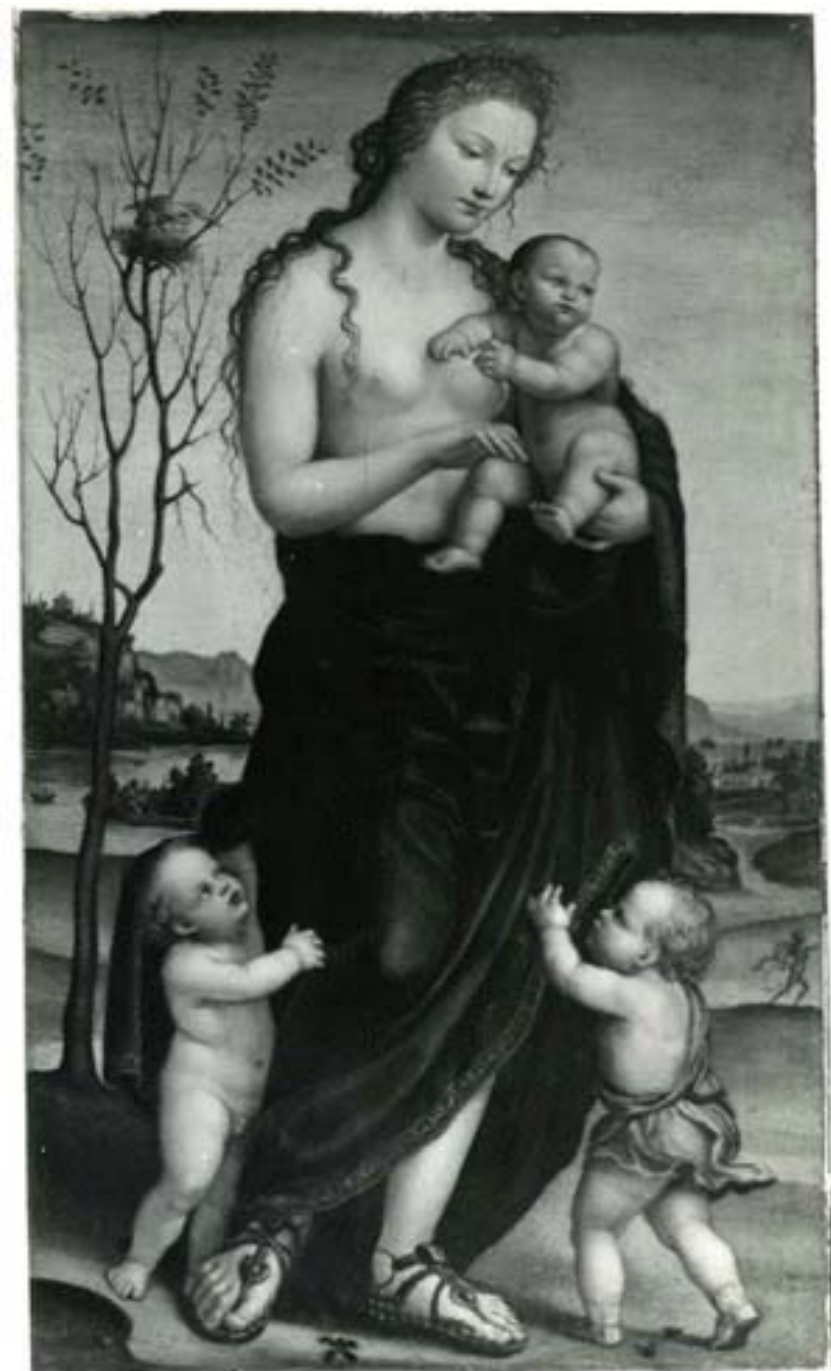

Figure 13. Giovanni Antonio Bazzi, Charity, 1510 (now lost). Photograph: Courtesy of the Kaiser Friedrich Museum, Berlin.

In Terrestrial Love and Celestial Love, the first love dichotomy between human love versus spiritual love is visualized in the right segment of the painting. This is the realm of Celestial Venus where a semi-nude woman is seated on rock in a fertile landscape with blooming trees. Surrounding her are three putti or cupids, one dormant, one playful, and another seeking to be nursed. Warmly, the woman embraces her hungry putto, while modestly covers part of her lower body. Bazzi's composition recalls the Christian Renaissance topos of an allegory of Charity, as seen in Raphael's Charity, a drawing of 1505 at the Ashmolean Museum in Oxford. In his previous paintings and drawings on the theme of Charity, Bazzi was also inspired by the marble sculpture of Jacopo della Quercia's Charity of 1418 in the Palazzo Pubblico of Siena. Between 1508 and 1510, Bazzi depicted Charity in a painting composed vertically with a bare-breasted woman standing in a contrapposto stance, embracing one of her infants while she is being tugged by the other two putti (Figure 13, the painting is now lost but it was originally at the Kaiser Friedrich Museum in Berlin, Germany). ${ }^{53}$ A parallel event occurs in

\footnotetext{
${ }^{53}$ I am grateful to Dr. Roberto Contini, Museum Curator of the Kaiser Friedrich Museum in Berlin, Germany, for his invaluable assistance and information about the painting. Gustav Friedrich Wagen acquired the painting during his Italian journey of 1841/42,
} 
the branches of the tree behind Charity. In a bird's nest there is a pelican feeding her newborns, a traditional Christian icon for a symbol of love and charity that can also be seen in an engraving of Baccio Baldini after Andrea Mantegna's Charity/Caritas in Tarot Card 38 of $1490 .^{54}$

Furthermore, inspired by his Roman artistic sojourn, Bazzi appropriated a pagan image of a Roman mother earth seated in a landscape with her playful putti, as seen in Tellus or Venus Genetrix, a marble frieze of 9 BCE from the Ara Pacis in Rome (Figure 14). In the painting it is clear that the putto seeking nursing is associated with motherly love (agape) - a mother nursing her child symbolizes the personification of love. Bazzi conflated the symbolisms of pagan agape and Christian motherly love or Caritas (Charity).

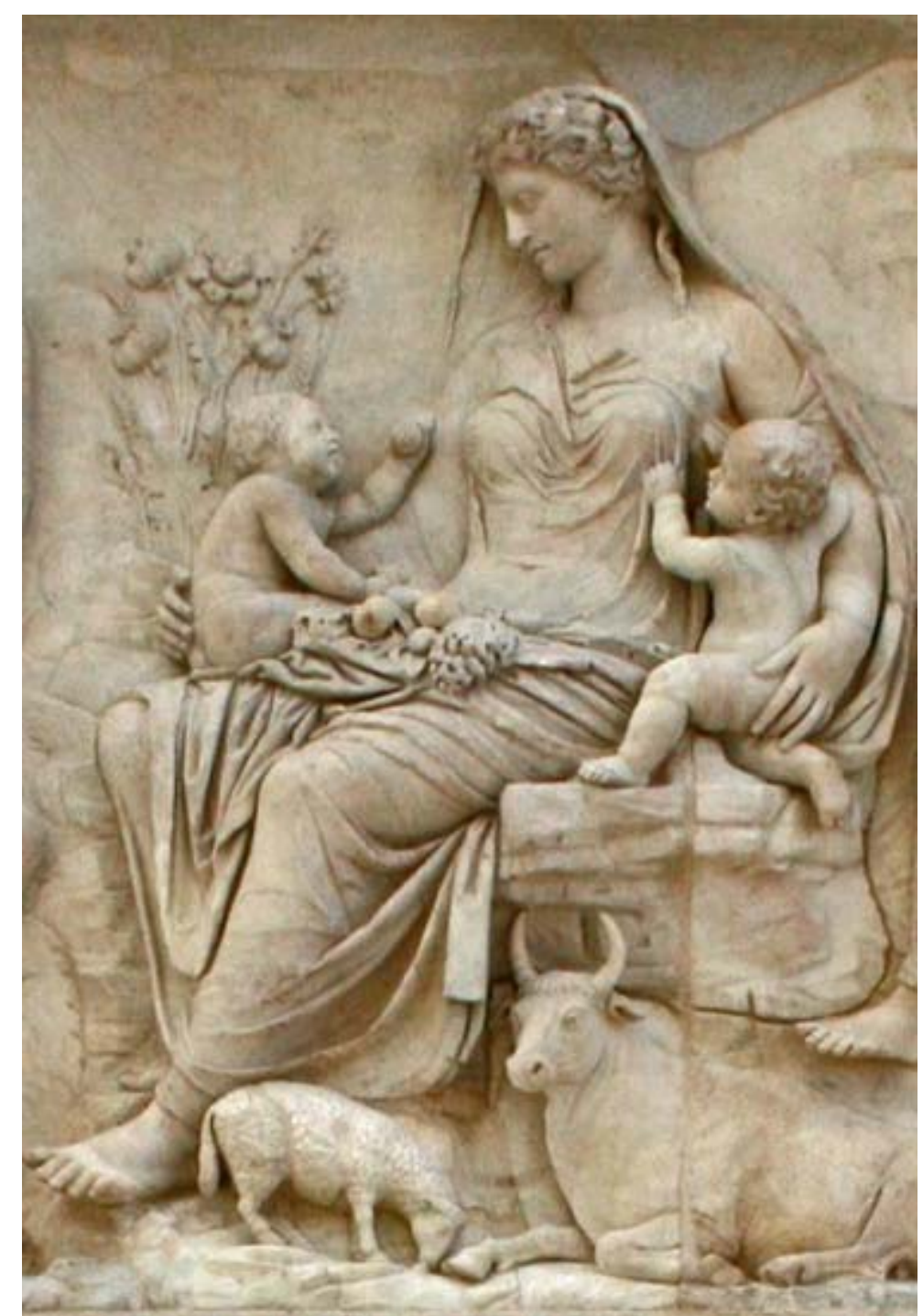

Figure 14. Tellus, Mother Earth or Venus Genetrix, 9 BCE, det., marble relief. Ara Pacis, Rome.

from Cochetti, an art dealer residing in Rome. In the museum's inventory from 1845 till 1878, Bazzi's Caritas was attributed to Baldassare Peruzzi (1481-1536). But in 1883, when a new catalogue was completed, the painting became attributed to Sodoma.

${ }_{54}$ See James Hall, Dictionary of Subjects and Symbols in Art (New York: Harper and Row, Publishers, 1974), p. 238; and Guy de Tervarent, Attributs et Symboles dans l'art profane (Geneva: Droz, 2000), p. 77. 
The significations of the other two putti are more complex. In the foreground, Bazzi's sleeping putto reveals several artistic appropriations. Once again, Bazzi sought inspiration from Nicoletto's engravings, in particular from The Fate of the Evil Tongue of 1507, at the Metropolitan Museum of Art in New York (Figure 15). In the engraving, on the second step of the circular altar there is an abbreviated Latin inscription from Proverbs 10:31: "lingua pravorum peribit" (The mouth of the righteous brings forth wisdom). ${ }^{55}$ This imagery is an allegory against slander, a non-charitable act. Another possible source of inspiration for the sleeping putto are classical literary and visual sources, for instance a type of ancient Roman fountain representing Eros sleeping, found on a marble sculpture of the 2nd century CE of the Roman Imperial period, now in the Monte Carlo Museum of Art (Figures 16 and 17); another such sculpture is in Nicosia Museum in Cyprus. Perhaps another traditional inspirational motif for Bazzi was the known classical literary reference from Plato's epigram on Eros sleeping by a fountain "Guide thy steps here in silence, lest through disturb the boy lapped in soft sleep, ${ }^{, 56}$ known in the Renaissance through Book XVI of the Palatine Anthology. ${ }^{57}$

\footnotetext{
55 The full verse reads: "Os iusti parturiet sapientiam lingua pravorum peribit" (The mouth of the righteous brings forth wisdom, But the perverse tongue will be cut out) [NRSV]. Nicoletto signed in the plate on the foremost pillar of the portico in the center: "NIC MVT".

56 See J. Campbell, The Cabinet of Eros: Renaissance Mythological Painting and the Studiolo di Isabella d'Este (London: Yale University Press, 2004), p. 96, n. 32. The Palatine Anthology was published in Florence in 1494 and in Venice in 1503.

${ }^{57}$ See Campbell, The Cabinet of Eros, p. 96, n. 33.
} 


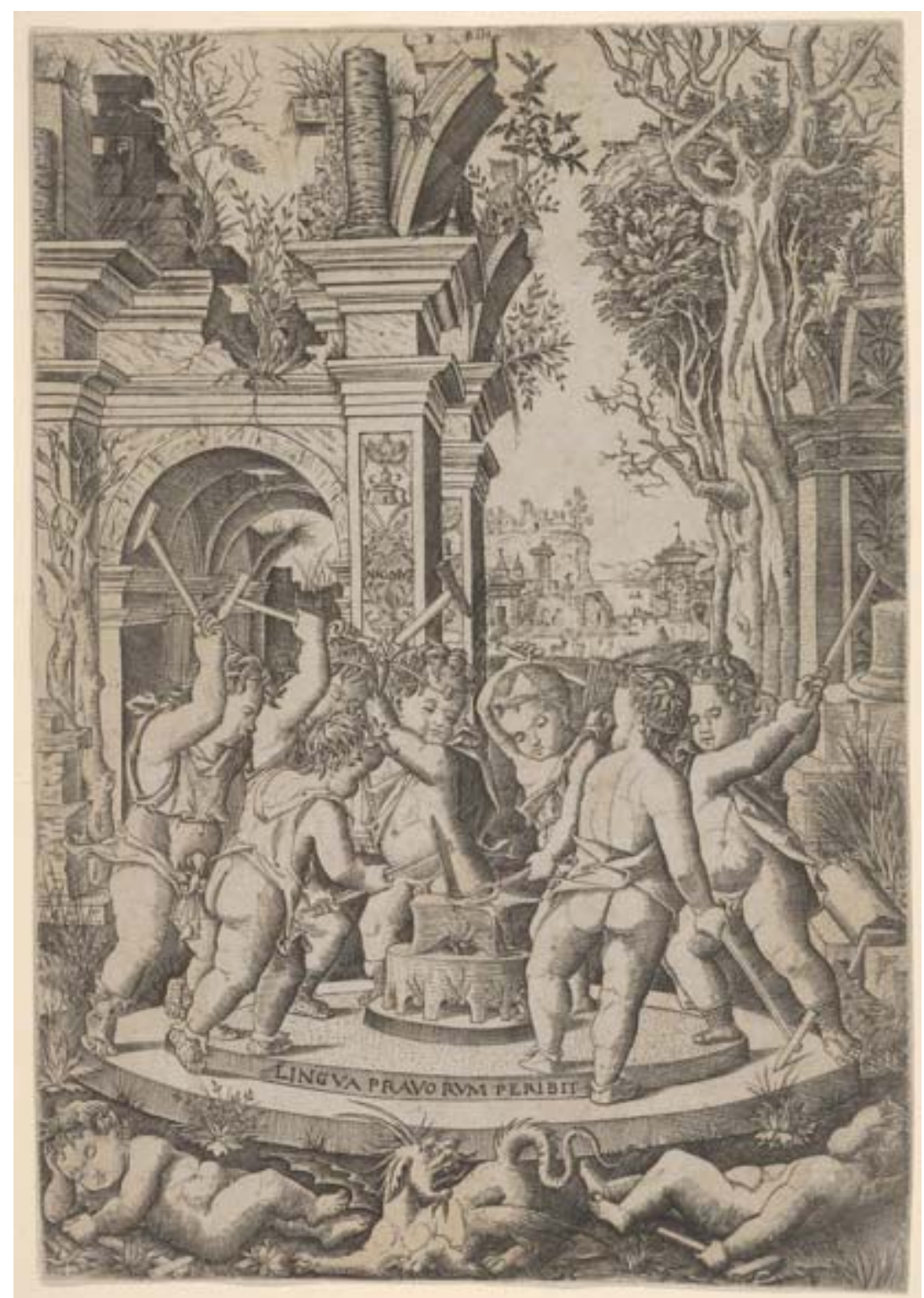

Figure 15. Nicoletto da Modena, Fate of the Evil Tongue, 1507. Metropolitan Museum of Art, New York (Acc No. 29.44.30).

Still, the meaning of this putto's placement is unclear. Perhaps the sleeping putto has nursed and is content and is now sleeping peacefully. He has been filled with motherly love from sacred love or Charity. Or it may be that the putto personifies the absence of carnal desire or love since he is resting in the proximity of sacred love (in the personification of Celestial Venus) and there is no need in seeking profane love. 


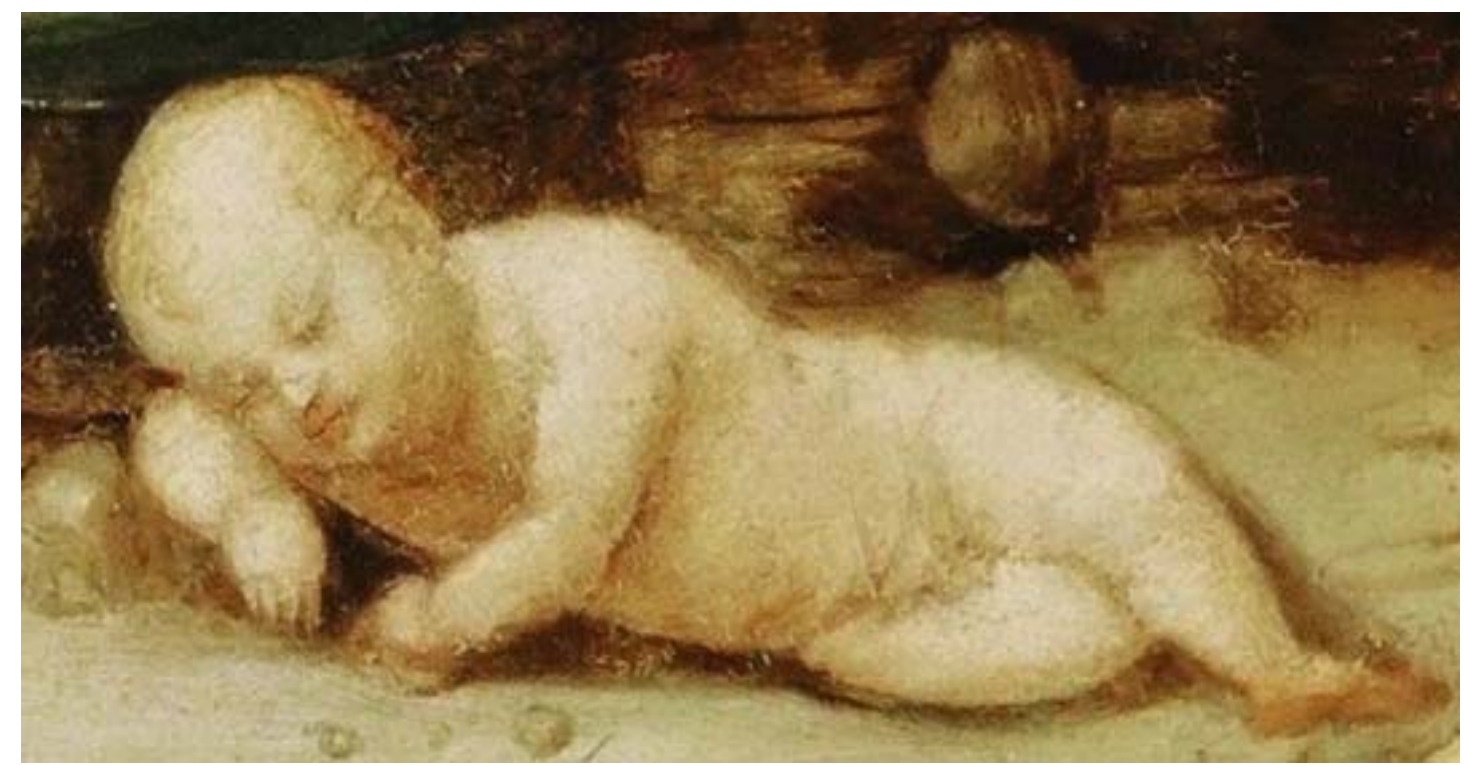

Figure 16. Giovanni Antonio Bazzi, Sleeping putto, 1509, det. from Celestial Love, Musée du Louvre, Paris.

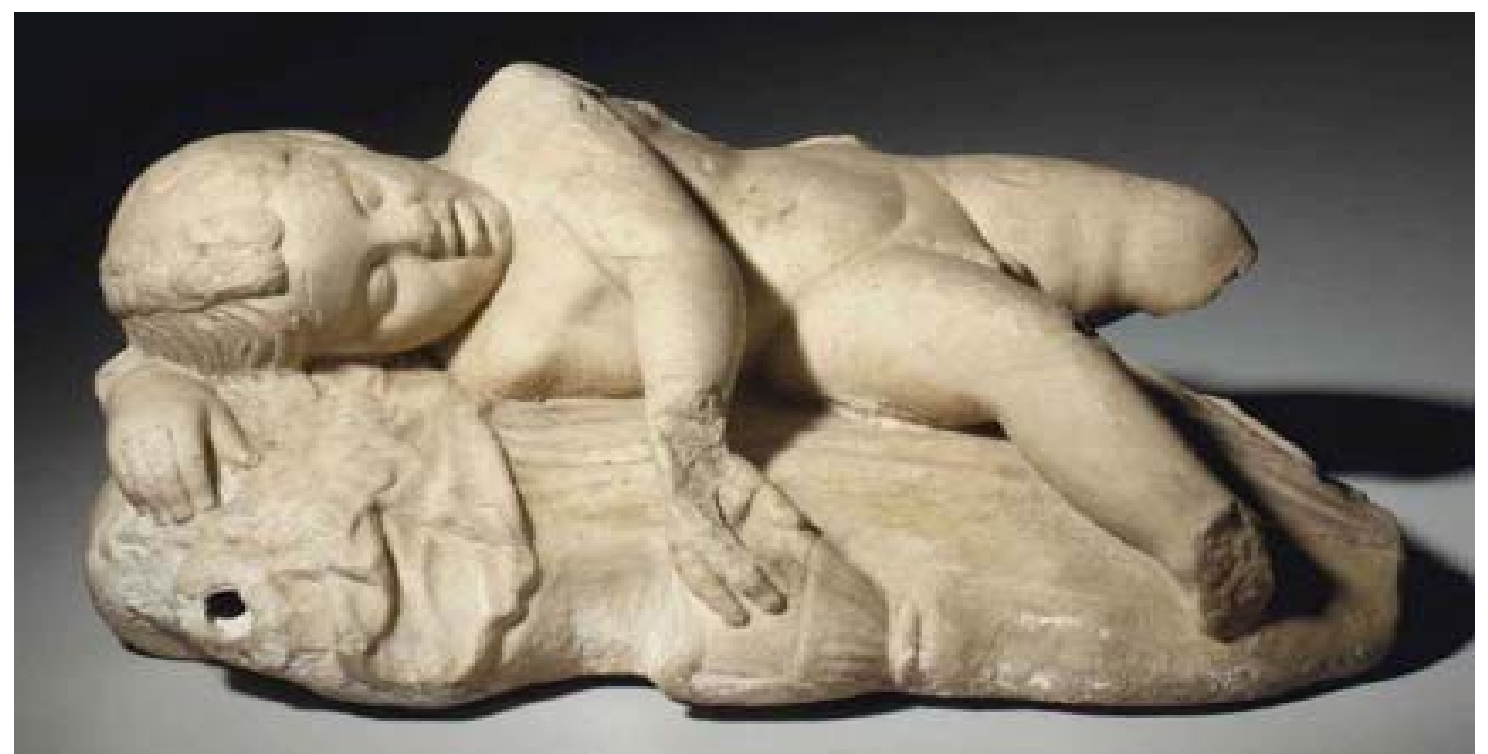

Figure 17. Fountain with Eros sleeping, Roman, 1st part of 2nd century (flipped image for comparison). Museum of Art, Monte Carlo.

The putto behind the seated figure (Celestial Venus) is different from the other two nude putti. This angelic putto with wings and transparent attire, crowned with flowers and holding a garland of flowers, is actively climbing over the rocks in order to seek his mother's attention (Figure 18). He can be identified as Anteros (a Greek word for love returned or counter-love), alluding to spiritual love or requited love. Andrea Alciato's emblem sheds some light on the meaning of Anteros. In the emblem of Anteros, id est, Amor virtutis (Anteros, that is Love of Virtue, compare Figures 18 and 19), Anteros is poetically identified as metaphysical love. $^{58}$

${ }^{58}$ See Andrea Alciato, Livret des emblems (Paris: Chrestien Wechel, 1536), citing the text below on the emblem about Anteros, id est, amor virtutis (Anteros, that is, Love of Virtue): "Tell me, where are your arching bows, where your arrows, Cupid, the shafts which you use to pierce the tender hearts of the young? Where is your hurtful torch, where your wings? Why does your hand hold 


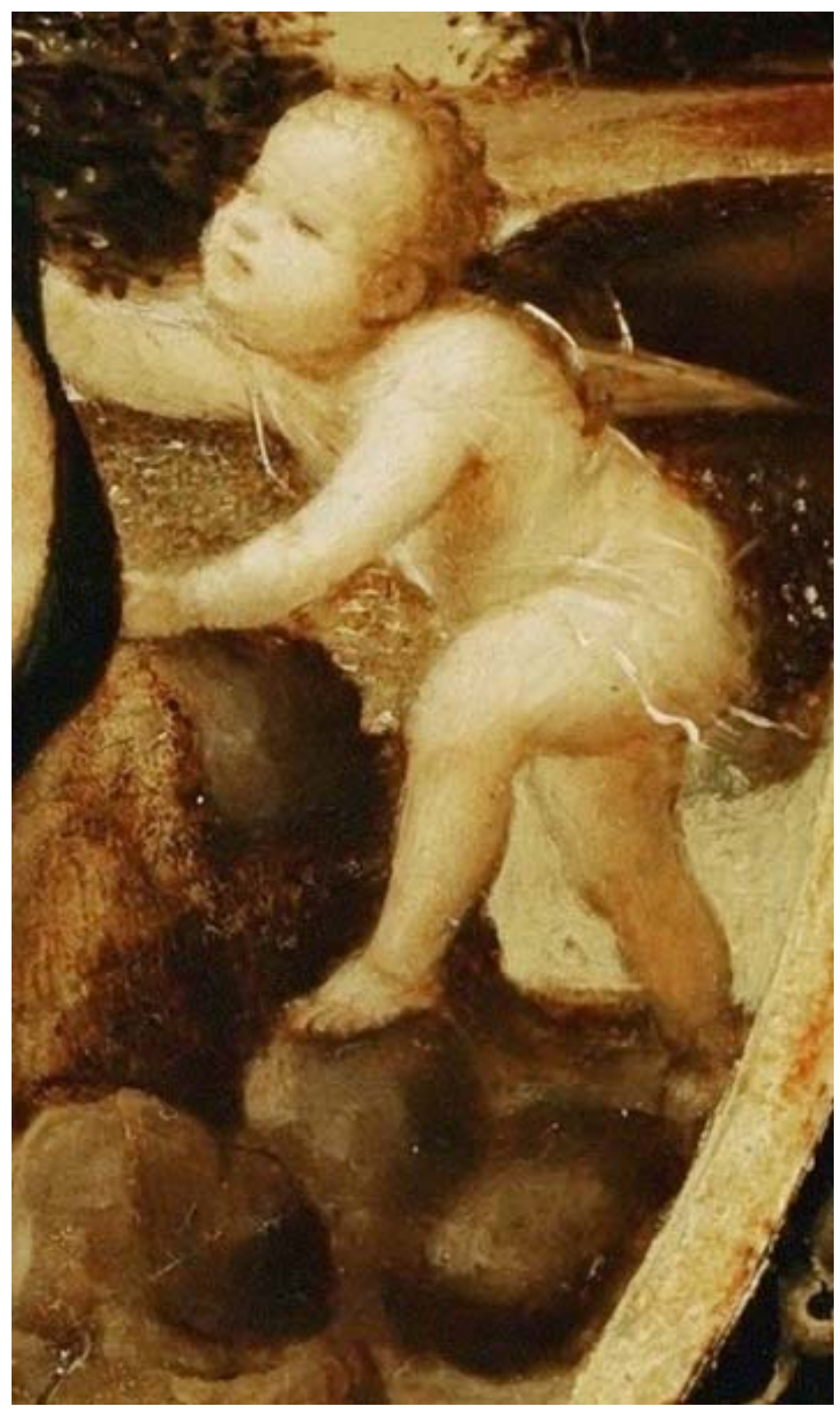

Figure 18. Giovanni Antonio Bazzi, Anteros, 1509, det. from Celestial Love, Musée du Louvre, Paris.

three garlands? Why do your temples wear a fourth? - Stranger, I have nothing to do with common Venus, nor did any pleasurable shape bring me forth. I light the fires of learning in the pure minds of men and draw their thoughts to the stars on high. I weave four garlands out of virtue's self and the chief of these, the garland of Wisdom, wreathes my temples".

The four garlands are a reference to the four cardinal virtues, justice, temperance, courage and wisdom. In the Alciato's Emblems 1534 edition, the figure of Anteros had wings.

See http://emblems.arts.gla.ac.uk/french/emblem.php?id=FALa081\#N3FALa081 (July 7, 2017). 


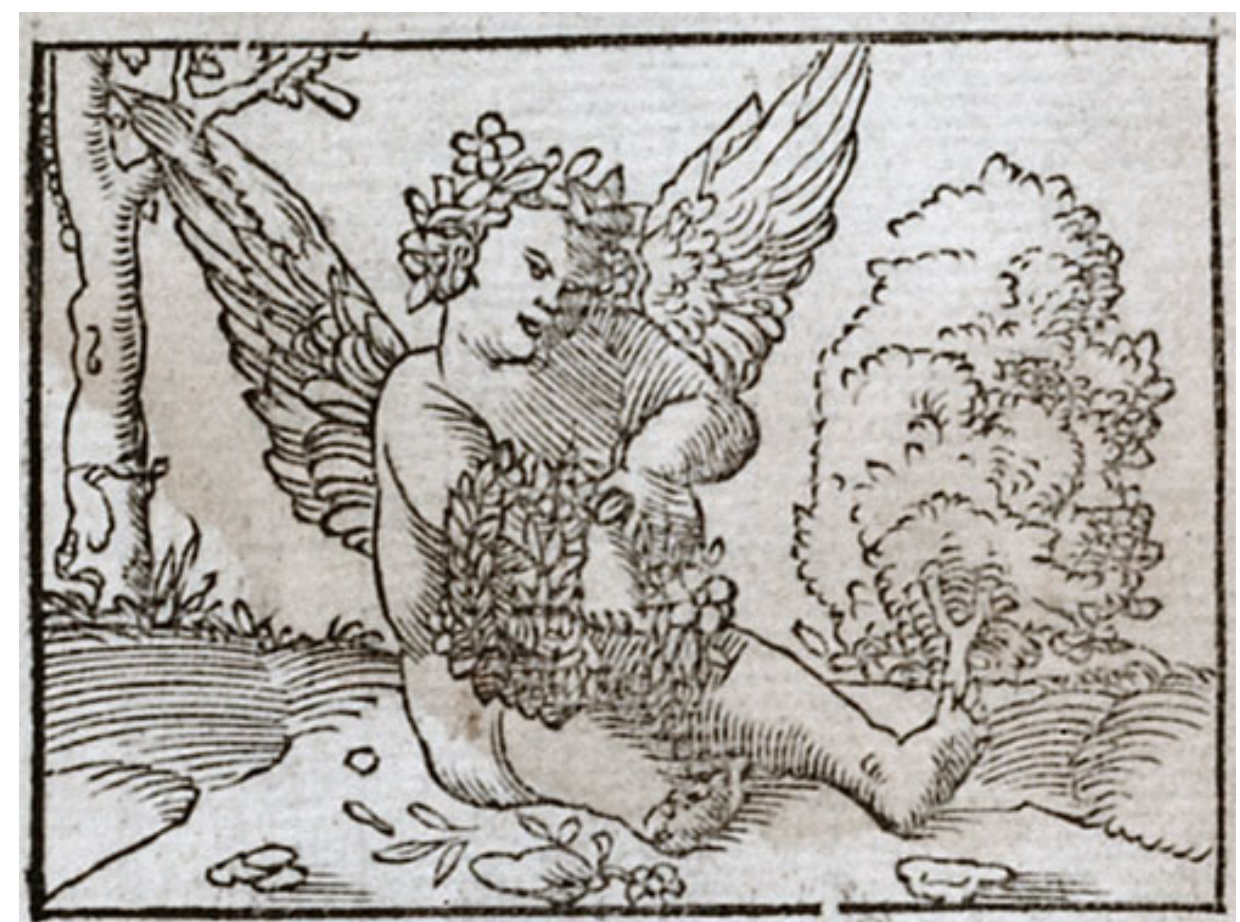

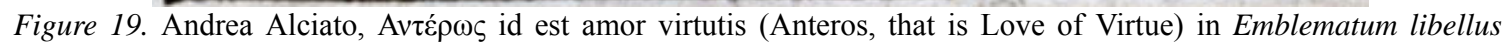
(Paris: Chrestien Wechel, 1534).

Perhaps together these three putti surrounding sacred love represent the various phases of achieving love requited: actively seeking love, content in having received love, and metaphysical pure protecting love. Thus, Bazzi personified on the right side of the painting agape - sacred love, or the personification of Celestial Venus.

The other side of the Bazzi's painting is less straightforward in its interpretation. This segment on the left depicts profane love personified as Terrestrial Love or Terrestrial Venus. A lovely kore wears classical attire, a red peplos, which reveals and conceals the young female body; her top garment falls down her shoulder revealing her sensual body, soft breast and long tresses. The red color of her peplos symbolizes the ardor of physical love, an attribute of the personification of terrestrial love, hence Terrestrial Venus. Paradoxically, the movement of her windblown peplos contrasts with her steady contrapposto stance. Terrestrial Venus and her companion Amor stand above a marble platform, a statuary ensemble. Terrestrial Venus gently extends her left hand to hold firmly onto Amor's hand and receives his gift of branches. Behind them a barren tree is hung with Armor's instruments of love: a shield, a bow with a broken string and a quiver with arrows. Terrestrial Venus' retributive actions - such as firmly holding his hand, directly gazing into his eyes - indicates that she is questioning or reprimanding Amor (Eros). Has Terrestrial Venus placed Amor's instruments of love on the tree to punish Amor's mischievous actions? Compositionally, Bazzi paralleled his imagery with the engraving of Marcantonio Raimondi's Reconciliation of Minerva with Cupid of 1500 (image flipped for comparison, Figure 20) where Cupid or Amor offers an olive branch to Minerva in order to obtain forgiveness for his misbehavior. Minerva accepts his repentance by holding his hand. Bazzi's painting is puzzling for two reasons: Amor's offering of a branch with leaves is barely visible, and the viewer wonders from which tree did Amor obtain the branch since the tree behind him, where his instruments are hanging, is leafless? 


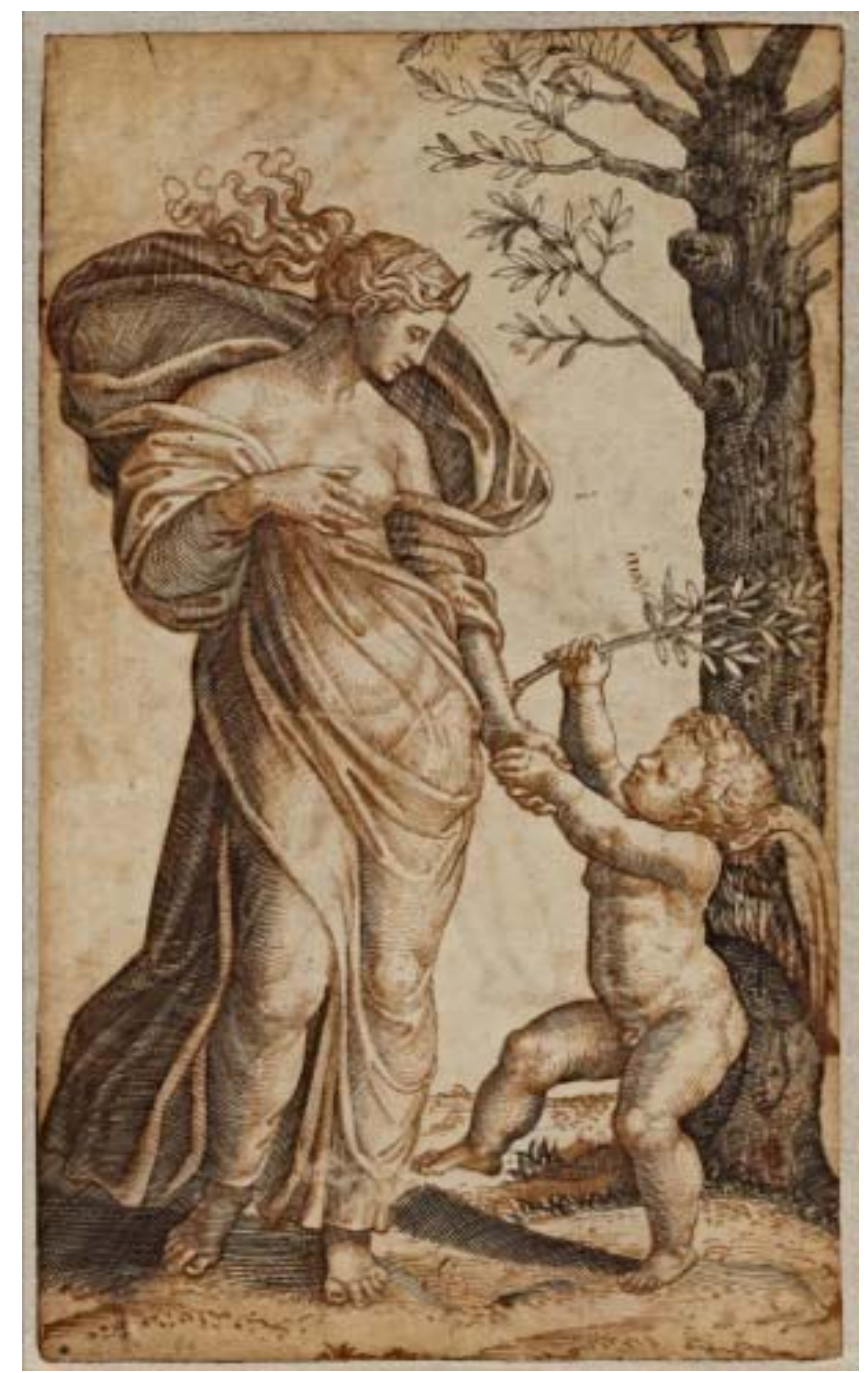

Figure 20. Marcantonio Raimondi, Reconciliation of Minerva with Cupid, 1500, engraving (flipped image for comparison). Iris \& B. Gerald Cantor Center for Visual Arts at Stanford University.

Another possible source for representing a mischievous Amor is Bazzi's appropriation of the theme of Eros and Anteros from ancient writings, such as Pliny the Elder's The Natural History (Book 36.2), Seneca's Phaedra (274), and Ovid's Fasti (4.1). The visual tradition also contributed to Bazzi's imagery, in this instance types of ancient sculptural relief of Eros and Anteros, like those of the 1st to 3rd centuries BCE from the sanctuary of Nitroides Nymphs and Apollo on the island of Ischia (near Naples), now in National Archaeological Museum in Naples; Renaissance material culture such as the descho da parto, for example, Masaccio's brother, Giovanni di Ser Giovanni Guido's (known as "Lo Scheggia") Desco da parto of 1450 in San Giovanni Valdarno (Christie's Auction, Figure 21); as well as from the pictorial emblematic tradition. 


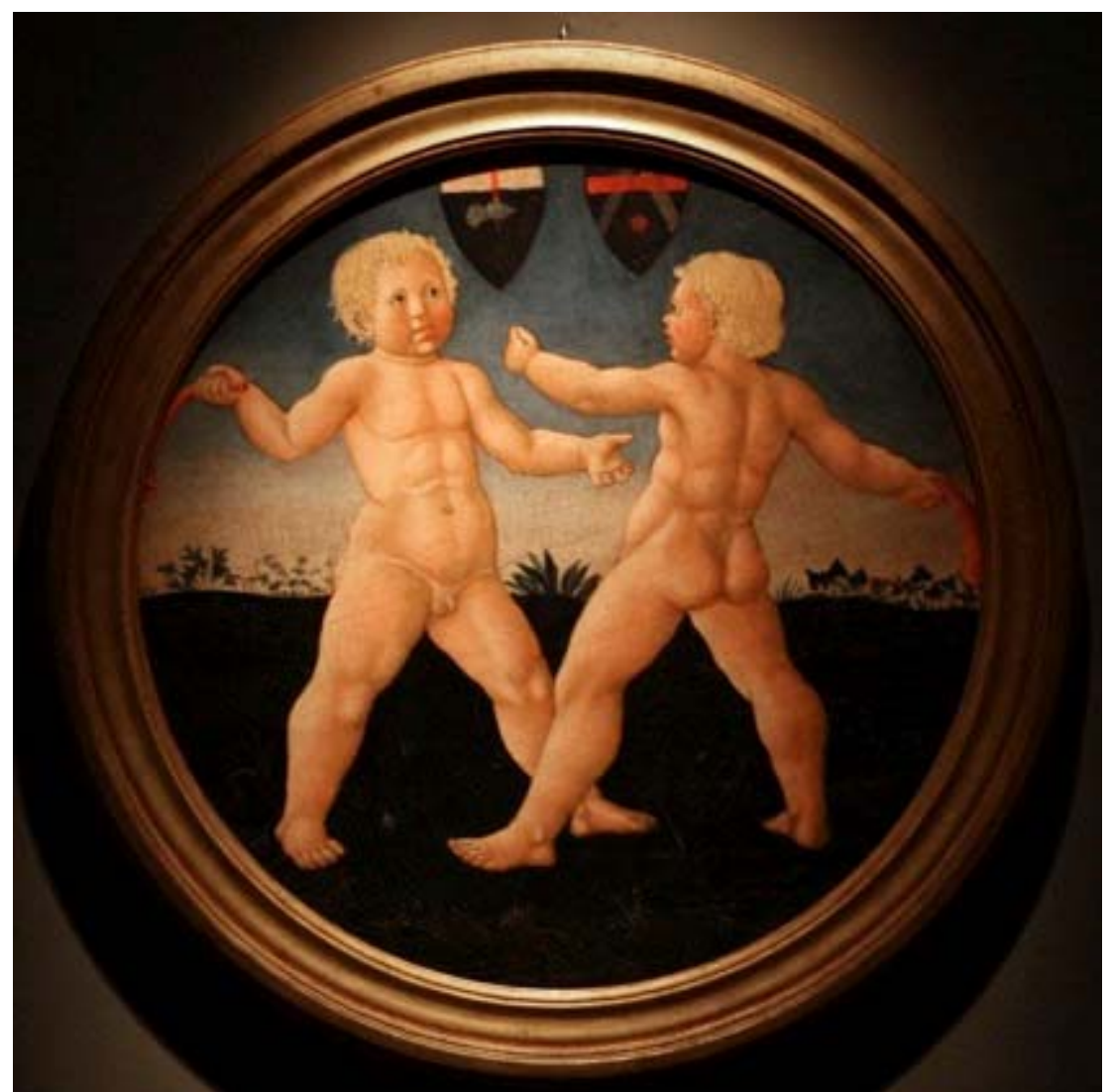

Figure 21. Lo Scheggia, Desco da parto (Eros and Anteros). Photo courtesy: Moretti, Florence London (n.352) and photographer Sailko.

It is tempting to make this comparison with the fresco painting of Punishment of Eros of $25 \mathrm{BCE}$ from the House of Punished Love in Pompeii (now in the National Archaeological Museum in Naples, Figure 22), but of course Bazzi would not have seen this imagery since Pompeii was not unveiled until 1830. In this small fresco painting Aphrodite is seated on a rock embraced by Anteros who guides her to look down in the direction of Eros, who is crying for having lost his bow and arrows and for being restrained by another woman. 


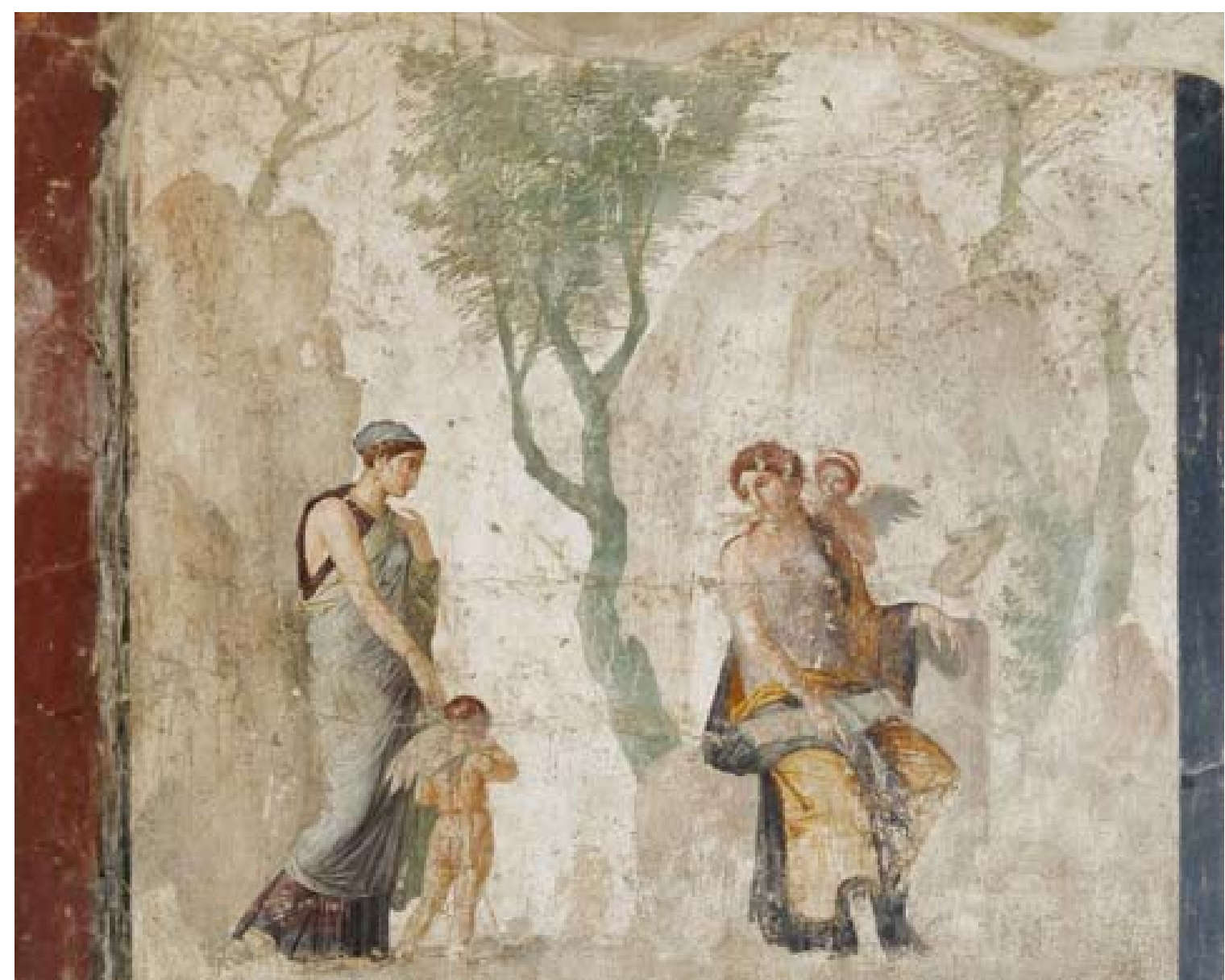

Figure 22. Eros and Anteros, 25 BCE. Fresco from the House of Punished Love. Pompeii VII, 2, 23. Now in the National Archaeological Museum, Naples (Inv. 9257).

The emblematic tradition fuses the ancient literary tradition with Renaissance culture. In the emblematic tradition, the conceits in ancient writings - for example, Ovid's Fasti (4.1) - Venus (Aphrodite) is referred as the mother of Twin Loves, Eros and Anteros, as visualized in Andrea Alciato's emblems. Eros and Anteros represent both physical and metaphysical love. In Emblem 72 (Figure 23), Anteros, Amor virtutis, alium Cupidinem superans (Anteros, Love of Virtue, conquering the other Love), Alciato visualized a winged Anteros binding a smaller Eros to a tree, while a blazing fire consumes the bow and arrows of sensual love where Anteros is punishing Eros' misbehavior or is trying to control Eros' ardor. ${ }^{59}$

\footnotetext{
${ }^{59}$ See Alciato, Livret des emblems, citing the text below on the emblem about Amor virtutis alium Cupidien superans (Anteros, Love of Virtue, conquering the other Love):

"Nemesis has fashioned a form with wings, a foe to Love with his wings, subduing bow with bow and flames with flame, so that Love may suffer what he has done to others. But this boy, once so bold when he was carrying his arrows, now weeps in misery and has spat three times low on his breast. A wondrous thing - fire is being burned with fire, Love is loathing the frenzies of Love". See http://www.emblems.arts.gla.ac.uk/alciato/emblem.php?id=FALa072 (July 30, 2017). See also, Claudia Corti, "Shakespeare the emblematist", in Michele Marrapodi, ed., Shakespeare and the Visual Arts: The Italian Influence (New York: Routledge, 2017), Part I, Chapter 1, n.p: "The fire surrounding the andirons would actually suggests the physical passions of Eros and the chaste emotions of Anteros, while the image as a whole would remind its beholder of the superiority of spiritual love"; Jean Céard, "The Devil and Lovesickness: Views of Sixteenth-Century Physicians and Demonologists", in Eros and Anteros: The Medieval Traditions of Love in the Renaissance, ed. Donald A. Beecher and Massimo Ciavolella (Toronto: Dovehouse Editions, 1992), pp. 33-47; and R.V. Merrill, "Eros and Anteros", Speculum 19 (1944), pp. 256-84; Erwin Panofsky, Studies in Iconology (New York: Harper and Row, 1967), pp. 122, 126, and 166, on Anteros and Eros.
} 


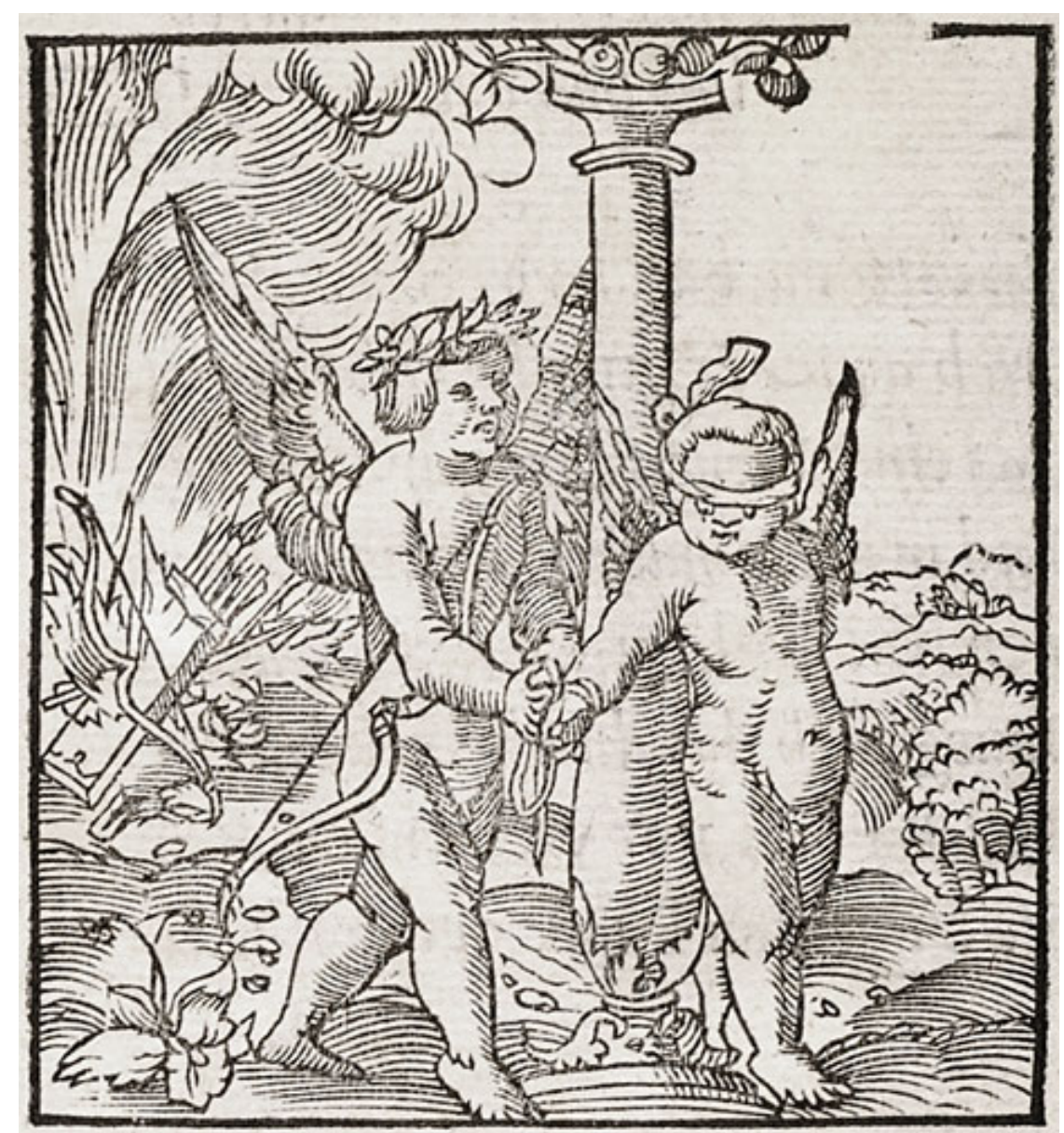

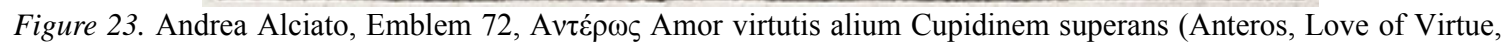
conquering the other Love) in Emblematum libellus (Paris: Chrestien Wechel, 1542).

Earlier mentioned, in another of Alciato's emblems, Anteros, id est, Amor virtutis (Anteros, that is Love of Virtue), Anteros is poetically identified as metaphysical love (compare Figures 19 and 23). ${ }^{60}$ Alciato is appropriating the Renaissance Neoplatonic interpretation of Marsilio Ficino's dual love, portrayed by the two Venuses: Humanitas (Terrestrial) and Urania (Celestial).

The myth of Venus's two loves, Eros and Anteros, is interpreted in ancient mythology as well as in Renaissance philosophy. One interpretation from antiquity is Lucius Apuleius's Metamorphoses or Golden Ass (170/180 CE), in which Amor plays a dual role: as Eros, he represents the negative aspects of love - erotic love - and as Anteros he represents positive aspects of love, spiritual love. ${ }^{61}$ In Neoplatonism, Ficino's interpretation of Plato's love is also based on the myth of Venus' two loves or her rival sons Eros and Anteros, hence Neoplatonic love is love of virtue with Anteros and not the opposite, Eros love or erotic love. ${ }^{62}$

Thus in Bazzi's Terrestrial Love and Celestial Love, the imaginary vertical axial separated the two types of love depicted - profane love and sacred love - as well as unifying the whole composition under the theme of

\footnotetext{
60 See n. 58.

${ }^{61}$ See Peggy Muñox Simonds, Myth, Emblem, and Music in Shakespeare's Cymbeline (Cranbury, NJ: Associated University Presses, 1992), pp. 111-16, referring to Alciato's Eros and Anteros.

62 See S. R. Jayne, trans. and ed., Marsilio Ficino's Commentary on Plato's Symposium on Love (Irving, TX: Spring Publications, 1985, superseding the 1944 translations from Marsilio Ficino's 1475 edition), pp. 117-118.
} 
the triumph of love, represented by the suspended instruments of love on the branch of a tree. This triumph of love is visualized in a paysage moralisé. In Italian Renaissance culture, these two types of love are conflated with two notions: in pagan mythology, 1) the children of Venus, Eros and Anteros, who respectively represent amor vulgaris and amor divinus; and 2) in Christian philosophy or Renaissance Neoplatonism, amor vulgaris became profane love while amor divinus or agape became sacred love or charity. ${ }^{63}$ The association of the children of Venus to the realms of Venus depends as well on her terrestrial or celestial origin, which formulates another level of symbolic allusions.

There are two notions about Venus' origins: one claiming that Venus rose out of the sea foam (Venus Urania or Celestial Venus or Heavenly Venus) ${ }^{64}$ The other claims that Venus was born from the union of Jupiter/Zeus and Juno/Dione, hence being Venus Pandemos (Earthly or Terrestrial Venus), ${ }^{65}$ thus referring to the Neoplatonic concept of the Twin Venuses or Two Venuses. These concepts are exemplified in the representation of the Twin Venuses: Heavenly or Celestial Venus partakes of the intelligible world of Beauty, while Humanitas or Earthly Venus shares the corporeal world of bodily forms.

Ficino continued to emphasize that Venus-Urania or Celestial Venus (Heavenly Celeste) resided in the sphere of Angelic Mind because she was the essence of Saturn and she was born of no mother or matter. The second Venus (Earthly/Terrestrial Venus) or Venus-Humanitas resided in the sphere of World-Soul because she was formed or created out of the conception of Jupiter (Zeus) and Juno (Dione), since Jupiter partook of the faculty of the Rational Soul. Therefore, Venus' nature is two-fold: (1) Intelligence (Angelic Mind), hence referred to as Venus Urania or Celestial Venus (Heavenly Venus), and (2) World-Soul or Generative being, hence referred to as Venus Humanitas or Terrestrial Venus (Earthly Venus, Venus Volgare, or Venus Genetrix). ${ }^{66}$

When Celestial Venus is accompanied by her son Amor as Anteros, the form of love stems from the Intelligible world (Angelic Mind), and this love is called amor divinus (divine love or celestial love, and agape), because is a celestial gift, a charitable love, as it involves the highest faculty of the individual: the act of contemplation. But when Amor as Eros accompanies his mother Terrestrial Venus (Venus Humanitas) the form of love is called amor vulgaris (human love, erotic love) because it finds its source in the corporeal or physical world of humanity: in perceptions, sensations and desires.

Through Celestial Venus, love is stimulated to know the beauty of God, as this Venus has the love of God and donates (Caritas) it to Terrestrial Venus who in turn procreates the same beauty in other bodies so that they may also share the love of God. Love exchanges beauty for beauty; love is a desire to perceive beauty; hence beauty is the Good or God. Bazzi has manifested these ideals in his allegorical paintings about love, Amore Celeste and Terrestrial Love and Celestial Love (Figures 3 and 12).

\footnotetext{
63 See Cheney, Botticelli's Neoplatonic Images, p. 35.

${ }^{64}$ See Hesiod, Theogony, pp. 188-200: Hesiod, Theogony, Works and Days. Testimonia, ed. and trans. Glenn W. Most (Cambridge, MA: Harvard University Press, Loeb Classical Library, 2007); and Jayne, Marsilio Ficino's Commentary on Plato's Symposium on Love, p. 53, on Ficino's comments about the origin of Venus.

${ }^{65}$ See Homer, Iliad, 3.374, eds. and trans., William F. Wyatt and A. T. Murray, Iliad, Vol. 1: Books 1-12 (Cambridge, MA: Harvard University Press, Loeb Classical Library, 1999); Odyssey, 8.288, eds. and trans. George E. Dimock and A. T. Murray, Odyssey, Vol. 1: Books 1-12 (Cambridge, MA: Harvard University Press, Loeb Classical Library, 1919; and the Homeric Hymn to Aphrodite, ed. and trans. H. G. Evelyn-White (Cambridge, MA: Harvard University Press, Loeb Classical, 2003 ), Book 5.

${ }^{66}$ See Jayne, Marsilio Ficino's Commentary on Plato's Symposium on Love, pp. 115-118.
} 


\section{Conclusion}

Stylistically and iconographically, Bazzi visualized the classical dilemma of the struggle between Eros and Anteros: love and counter-love, or love given and love returned, and the Neoplatonic conciliation between pagan and Christian love, physical and metaphysical love through the symbolism of fire further expounded by Ficino in his De Amore (On Love).

In studying the Renaissance Neoplatonic philosophy of Ficino, one notices that Ficino created two worlds: corporeal world or nature, which can only express bodily form, and the ideal world, which transcends beyond itself and is revealed as the intelligible world. Art, through the spirit of love, moves the soul to a new feeling, to a transcending appreciation of Beauty. These philosophical notions are integrated in Bazzi's allegorical paintings about love.

The cultural environment of Rome with its classical references and ancient architectural ruins were assimilated by Renaissance artists such as Botticelli, Nicoletto, Pinturicchio and Raphael, which provided Bazzi with an education about artistic and historical realms. Furthermore, the visual representations of the Cinquecento's artists, as demonstrated in Bazzi's Amore Celeste and the Terrestrial Love and Celestial Love, were enriched thematically and metaphorically by the intellectual milieu of Siena: with artists such as Pinturicchio; with the patronage of learned families such as the Chigi, Petrucci and Piccolomini, and with the accessibility to their libraries that held the writings of Neoplatonic philosophers such as Ficino and Pico and classists and poets such as Bembo, Colonna and the Sulpizio; and the emblematic sources from Alciato.

Bazzi was inspired by Ficino's agape that is a synonym for caritas or charity ${ }^{67}$ as union between divine love or amor divinus and erotic love or amor vulgaris. He visualized the symbolisms of these types of love in two different types of burning fires: divine or celestial love that conquers terrestrial physical or human love. This is why in Terrestrial Love and Celestial Love, Bazzi left suspended on the tree the instruments of Amor, perhaps to suggest a moral message and a reminder to the newlyweds about the importance of both types of loves in a marriage - or to tease the viewer by presenting the dilemma of what love to choose: profane or sacred. Curiously, in the bushes behind the figure of Celestial Love, Bazzi has hidden himself to wonder on the viewer's decision. And in Amore Celeste, Bazzi complemented the ardor of love (a furor amorous) with a message of purification of the soul, for the soul to achieve peace and celebrate life.

\section{References}

Alciato, A. (1534/36). Emblematum libellus (Emblematic treatise). Paris: Chrestien Wechel.

Allen, M. J. B. (1981). Marsilio Ficino and the Phaedran Charioteer. Los Angeles, CA: University of California Press.

Allen, M. J. B. (1983). The Platonism of Marsilio Ficino. Los Angeles, CA: University of California Press.

Allen, M. J. B. trans. and ed. (2008). Marsilio Ficino Commentaries on Plato (vols. 2). Cambridge: Harvard University Press.

Allen, M. J., \& Rees, V. (2002). Marsilio Ficino: His theology, his philosophy, his legacy. Leiden: Brill.

Balas, E. (1995). Michelangelo's Medici Chapel: A new interpretation. Philadelphia: American Philosophical Society.

Baromg, A., \& Cashford, J. (1993). The Myth of the Goddess. Baltimore: Arkana, Penguin Books.

Bartalini, R. (1990). Giovanni Antonio Bazzi. In A. Bagnoli et al. (Eds.), Domenico Beccafumi e il Suo Tempo (Domenico Beccafumi and His Time) (pp. 228-52). Milan: Electa.

Bartalini, R., \& Zombardo, A. (2012). Antonio Bazzi, il Sodoma: fonti documentarie e letterarie (Antonio Bazzi, Il Sodoma: sources of documents and letters). Vercelli: Società Storica.

Bayer, A. (2009). Art and Love in Renaissance Italy. New York: Metropolitan Museum of Art.

${ }^{67}$ See Amos Edelheit, Ficino, Pico and Savonarola (Leiden: Brill, 2008), pp. 167-68. 
Bettarini, R., \& Barocchi, P. (1976). Giorgio Vasari, Le vite de’ piú eccellenti pittori, scultori et architettori nelle redazioni del 1550 e 1568 (The Lives of the painters, sculptors and architects in the editions of 1550 and 1568). Florence: S.P.E.S.

Blavatsky, H. P. (1919). Isis Unveiled: A Mater-key to the mysteries of ancient and modern science and theory (vols. 2). Point Loma, CA: The Aryan Theosophical Press.

Bohn, R. K. (1973). The Isis Episode in Apuleius. The Classical Journal, 68(3) (Feb-Mar), 228-31.

Campbell, S. J. (2004). The Cabinet of Eros: Renaissance Mythological Painting and the Studiolo di Isabella d'Este. London: Yale University Press.

Carli, E. (1950). Mostra delle opera di Giovanni Antonio Bazzi detto Il Sodoma (Exhibition on the works of Giovanni Antonio Bazzi called Il Sodoma). Siena: Pinacoteca.

Céard, J. (1992). The Devil and Lovesickness: Vies of sixteenth-century physicians and demonologists. In D. A. Beecher, \& M. Ciavolella (Eds.), Eros and Anteros: The Medieval Traditions of Love in the Renaissance (pp. 33-47). Toronto: Dovehouse Editions.

Chastel, A. (1958). Note sur la Sphinx à la Renaissance (Note on the sphinx in the renaissance). Rome: Archivio di Filosofia.

Chastel, A. (1975). Marsile Ficin et L'Art (Marsilio Ficino and Art). Geneve: Droz.

Cheney, L. D. G. (1993). Botticelli’s Neoplatonic Images. Potomac, MD: Scripta Humanistica.

Cheney, L. D. G. (2002). Botticelli's interpretation of “Antiquity”: Camilla/Minerva and the Centaur. In Discovery (Spring):1-14.

Christiansen, K. (1998). Painting in Renaissance Siena, 1420-1500. New York: The Metropolitan Museum of Art.

Corti, C. (2017). Shakespeare the emblematist. In M. Marrapodi (Ed.), Shakespeare and the Visual Arts: The Italian Influence (Part I, Chap. 1). New York: Routledge.

Curran, B. (2007). The Egyptian Renaissance: The Afterlife of Ancient Egypt in Early Modern Italy. Chicago, ILL: University of Chicago Press.

Cust, R. H. H. (1906). Giovanni Antonio Bazzi, Sodoma: The Man and the Painter. London: John Murray.

de Tervarent, G. (2000). Attributs et Symboles dans l'art profane (Attributes and Symbols in profane art).Geneva: Droz.

Downing, C. (1984). The Goddess: Mythological images of the feminine. New York: Crossroad.

Edelheit, A. (2008). Ficino, Pico and Savonarola. Leiden: Brill.

Emison, P. (1995). The Paysage Moralisé. Artibus et Historiae, 16(31), 125-137.

Evelyn-White, H. G. trans. (1914). Hesiod, “To Athena”. In The Homeric Hymns and Homerica (pp. 443-55). Cambridge, MA: Harvard University Press, The Loeb Classical Library.

Evelyn-White, H. G., ed. trans. (2003). Homeric Hymn to Aphrodite. Cambridge, MA: Harvard University Press, Loeb Classical Library.

Farnell, L. R. (1971). The Cult of the Greek States (vols. 2). Chicago: Aegaean Press.

Finamore, J. (1993). Iamblichus on light and transparent. In H. J. Blumenthal, \& E. G. Clark (Eds.), The Divine Iamblichus (pp. 55-64). Bristol: Classics Press.

Forrest, M. I. (2013). Isis Magic. Portland, OR: Abiegnus House.

Garin, E. (1942). Giovanni Pico della Mirandola, De hominis dignitate (On the dignity of man). Florence: Vallecchi.

George, E., Dimock, G. E., \& Murray, A. T. (1919). Odyssey. Cambridge, MA: Harvard University Press, Loeb Classical Library. Godwin, J. (2003). Colonna, F. Hypnerotomachia Poliphili: The Strife of Love in a Dream (1499). London: Thames and Hudson. Greenhalgh, M. (1982). Donatello and his sources. London: Duckworth.

Hall, J. (1974). Dictionary of subjects and symbols in art. New York: Harper and Row.

Hassan, S. (1953). The Great Sphinx and its Secrets. Cairo: Government Press.

Hind, A. M. (2006). Early Italian Engraving: A critical catalogue with complete reproductions of all the prints described (vols. 5). Centre, CT: Martino Pub.

Hyman, A. (1976/78). Giovanni Antonio Bazzi, Il Sodoma. New York: Garland Publications.

Jayne, S. R. trans. ed. (1985). Marsilio Ficino's Commentary on Plato’s Symposium on Love. Irving, TX: Spring Publications.

Kenny, E. J., ed. trans. (1998). Apuleius, The Golden Ass. Baltimore, MD: Penguin Books.

Kristeller, P. O. (19985). The Letters of Marsilio Ficino (vols. 3). New York: Ginko Press.

Lambert, G. (2015). Les Premières gravures Italiannes (The first Italian engravers). Paris: Éditions de la Biblothèque Nationale de France.

Lefkowitz, M. R., \& Maureen, B. F. (2005). Women's life in Greece and Rome. Baltimore, MD: John Hopkins University Press. Merrill, R. V. (1944). Eros and Anteros. Speculum, 19, 256-84. 
Most, G. W. ed. and trans. (2007). Hesiod, theogony, works and days. Testimonia. Cambridge, MA: Harvard University Press, Loeb Classical Library.

Nevola, F. (2007). Siena: Constructing the Renaissance City. New Haven: Yale University Press.

Panofsky, E. (1967). Studies in iconology. New York: Harper and Row.

Petherbridge, D. (2014). Graphic Intersections: Erga, Parerga and Pro-Erga. Journal of the International Association of Research Institutes in the History of Art (March), 83-98.

Poliziano, A. (1495/1500). Stanze per la Giostra (Poems for the Tournament). Florence: Lorenzo de Alopa.

Pomeroy, S. B. (1995). Goddess, Whores, Wives, and Slaves: Women in classical antiquity. New York: Schocken Books.

Raffini, C. (1998). Marsilio Ficino, Pietro Bembo, Baldassare Castiglione: Philosophical, Aesthetic, and Political Approaches to Renaissance Neoplatonism. London: Peter Lang.

Ragghianti, L. C. (1973). Il Libro de’ Disegni del Vasari (Vasari’s Book of Drawings) (vols. 2). Florence: Archittetura.

Randolph, A. W. B. (2004). Gendering The Period Eye: Deschi da Parto and Renaissance Visual Culture. Art History, $27,538-62$.

Remler, P. (2010). Egyptian Mythology A to Z. New York: Chelsea House.

Rensi, G. ed. and trans. (2003). Marsilio Ficino, De amore (On Love, 1484). Milan: SE SRL.

Romagnoli, E. (1835/1976). Biografia, cronologia de' bellartisti Senesi dall secolo XII e tutto il XVIII (Biography, chronology of Sienese artists from XII included XVIII) (vols. 12). Florence: S.P.E.S.

Simonds, P. M. (1992). Myth, Emblem, and Music in Shakespeare's Cymbeline. Cranbury, NJ: Associated University Presses.

Tarrant, H. (1999). Shadows of Justice in Apuleius' Metamorphoses. Hermathena, 167(Winter), 71-89.

Tedeschi, D. R. (1988/2008/2010). Sodoma. Rome: n.p.

Thompson, N. H. trans. (1992). Niccolò Machiavelli, The Prince (1513). New York: Dover.

Tozzi, M. T. (1951). Il Sodoma. Messina: d'Amico.

Wagner, M. F. (2002). Neoplatonism and Nature: Studies on Plotinus Enneads. New York: State University of New York Press. Waite, A. E. (1910/2005). The Hermetic and Alchemical Writings of Paracelsus. Whitefish, MO: Kessinger Publishing.

Wyatt, W. F., \& Murray, A. T. eds. and trans. (1999). Iliad. Cambridge, MA: Harvard University Press, Loeb Classical Library.

Zeri, F., \& Gardner, E. E. (1980). Italian Paintings: A Catalogue of the Collection of The Metropolitan Museum of Art. Sienese and Central Italian Schools. New York: Metropolitan Museum Press. 